\title{
Asian-Pacific consensus statement on the management of chronic hepatitis B: a 2008 update
}

\author{
Yun-Fan Liaw • Nancy Leung · Jia-Horng Kao - Teerha Piratvisuth · \\ Edward Gane · Kwang-Hyub Han · Richard Guan - George K. K. Lau • \\ Stephen Locarnini - for the Chronic Hepatitis B Guideline Working Party \\ of the Asian-Pacific Association for the Study of the Liver
}

Received: 24 January 2008/Accepted: 9 April 2008/Published online: 10 May 2008

(C) The Author(s) 2008

\begin{abstract}
Large amounts of new data on the natural history and treatment of chronic hepatitis B virus (HBV) infection have become available since 2005. These include long-term follow-up studies in large community-based cohorts or asymptomatic subjects with chronic HBV infection, further studies on the role of HBV genotype/ naturally occurring $\mathrm{HBV}$ mutations, treatment of drug
\end{abstract}

Other members of the working party: Rong-Nan Chien, Anuchit Chutaputti, Graham Cooksley, S. M. Wasim Jafri, Laurentius A. Lesmana, Seng-Gee Lim, Rosmawati Mohamed, Masao Omata, Pham Hoang Phiet, Shiv Kumar Sarin, Jose Sollano, Dong-Jin Suh, GuangBi Yao, Osamu Yokosuka.

\author{
Y.-F. Liaw $(\bowtie)$ \\ Liver Research Unit, Chang Gung University and Memorial \\ Hospital, 199, Tung Hwa North Road, Taipei, Taiwan \\ e-mail: liveryfl@so-net.net.tw \\ N. Leung \\ Department of Medicine, Alice Ho Miu Ling Nethersole \\ Hospital, Room 65, J6, 11 Chuen On Road, Taipo, \\ NT, Hong Kong \\ e-mail: leungwyn@ha.org.hk; nancyleung@cuhk.edu.hk \\ J.-H. Kao \\ Hepatitis Research Center, National Taiwan \\ University Hospital, 7 Chung-Shan South Road, \\ Taipei 100, Taiwan \\ e-mail: kaojh@ntu.edu.tw \\ T. Piratvisuth \\ NKC Institute of Gastroenterology and Hepatology, \\ Songklanagarind Hospital, Prince of Songkla University, \\ Hat Yai 90110, Thailand \\ e-mail: teerha.p@psu.ac.th \\ E. Gane \\ NZ Liver Transplant Unit, Auckland, \\ New Zealand \\ e-mail: EdGane@adhb.govt.nz
}

resistance and new therapies. In addition, Pegylated interferon $\alpha 2 \mathrm{a}$, entecavir and telbivudine have been approved globally. To update HBV management guidelines, relevant new data were reviewed and assessed by experts from the region, and the significance of the reported findings were discussed and debated. The earlier "Asian-Pacific consensus statement on the management of chronic hepatitis B"

\footnotetext{
K.-H. Han

Department of Internal Medicine, Yonsei University College of Medicine, Liver Cirrhosis Clinical Research Center,

Seoul, Korea

e-mail: gihankhys@yuhs.ac

R. Guan

Mount Elizabeth Medical Centre and National University

Hospital Singapore, 3 Mt Elizabeth, \#17-02,

Singapore 228570, Singapore

e-mail: rgyc5@singnet.com.sg

G. K. K. Lau

Department of Medicine, The University of Hong Kong,

Room 1838, Block K, Queen Mary Hospital,

102 Pokfulum Road, Hong Kong SAR, China

e-mail: gkklau@netvigator.com

S. Locarnini

Research \& Molecular Development, Victorian Infectious

Diseases Reference Laboratory, WHO Collaborating Centre

for Virus Reference \& Research, 10 Wreckyn Street,

North Melbourne, VIC 3051, Australia

e-mail: Stephen.Locarnini@mh.org.au

for the Chronic Hepatitis B Guideline Working Party of the Asian-Pacific Association for the Study of the Liver
} 
was revised accordingly. The key terms used in the statement were also defined. The new guidelines include general management, special indications for liver biopsy in patients with persistently normal alanine aminotransferase, time to start or stop drug therapy, choice of drug to initiate therapy, when and how to monitor the patients during and after stopping drug therapy. Recommendations on the therapy of patients in special circumstances, including women in childbearing age, patients with antiviral drug resistance, concurrent viral infection, hepatic decompensation, patients receiving immune-suppressive medications or chemotherapy and patients in the setting of liver transplantation, are also included.

Keywords Chronic hepatitis B - Liver cirrhosis . Hepatocellular carcinoma - Hepatitis B virus (HBV) . Interferon- $\alpha \cdot$ Pegylated interferon $\cdot$ Lamivudine . Adefovir · Entecavir · Telbivudine

\section{Introduction}

Since the third version of "Asian-Pacific consensus statement on the management of chronic hepatitis B" was published in June 2005 [1], pegylated interferon- $\alpha 2$ a (PegIFN- $\alpha 2 a)$, entecavir, and telbivudine have been approved globally and several updated guidelines on chronic hepatitis B virus (HBV) infection have been published [2-4]. Large amount of new data on the natural history and treatment of chronic HBV infection has also become available. These include long-term follow-up studies in community-based cohorts and asymptomatic subjects with chronic HBV infection, further studies on the role of HBV genotypes and naturally occurring HBV mutations, and treatment of drug resistance. In addition, new issues such as the "roadmap" concept toward more effective management of the condition and pharmacoeconomics of drug therapy are emerging. We have closely followed the progress in the field and invited experts from the Asian-Pacific region to review and assess relevant new data. The significance of the reported findings were discussed and debated during a 2-day expert meeting at Pattaya, Thailand, in November 2007. The 2005 update of the "Asian-Pacific consensus statement on the management of chronic hepatitis B" [1] was revised accordingly. The key terms used in the statement were also defined (Table 1). Then, the revised version was circulated for further comments and it was refined through electronic communications among the experts. The revised contents were presented and discussed at the Asian-Pacific Association for the Study of the Liver meeting in Seoul, Korea, in March 2008. The following is the final version of the updated consensus and recommendations on the management of chronic hepatitis B.

\section{Conceptual background}

HBV, pathogenesis, and natural course

Chronic HBV infection is a serious clinical problem because of its worldwide distribution and potential adverse sequelae. It is particularly important in the Asian-Pacific region where the prevalence of $\mathrm{HBV}$ infection is high. In this part of the world, the majority of HBV infection prevalence is acquired perinatally or in early childhood, and some patients may be superinfected with other viruses that may influence the clinical outcomes.

Previous studies revealed the presence of two replication pathways, namely, episomal and integrated forms, and reverse transcription process in HBV infection [5]. It has been recognized that covalently closed circular DNA plays a key role in the maintenance of chronic HBV infection [6]. As HBV is not usually cytopathogenic by itself, chronic HBV infection is a dynamic state of interactions among the virus, hepatocytes, and the host immune system. The natural course of chronic HBV infection in this geographic region can be divided into (i) immune-tolerant phase, (ii) immune clearance phase, and (iii) residual or inactive phase. HBV reactivation and relapse of hepatitis may occur in some patients who are in the residual or inactive phase.

Patients in the immune-tolerant phase are usually young, hepatitis $\mathrm{B}$ e antigen $(\mathrm{HBeAg})$ seropositive with high viral loads $\left(>2 \times 10^{6}\right.$ to $2 \times 10^{7} \mathrm{IU} / \mathrm{ml}$ or $>10^{7}-10^{8}$ copies $\left./ \mathrm{ml}\right)$ but normal serum alanine aminotransferase (ALT) and no or minimal clinicopathological changes. The results of a recent 5-year follow-up study have confirmed that adults in the immune-tolerant phase show minimal disease progression [7]. However, HBeAg-positive subjects older than 40 years with persistently "high normal" ALT may have significant hepatic necroinflammation or fibrosis [8]. During the immune clearance phase, hepatitis activity and even acute flares with serum ALT levels over 5 times upper limit of normal (ULN) may occur, and these may sometimes be complicated by hepatic decompensation. These ALT elevations and hepatitis flares are the result of host's immune responses against $\mathrm{HBV}$, such as HLA-class I antigen restricted cytotoxic T lymphocyte (CTL)-mediated response against HBV antigen(s) expressed on hepatocytes with resultant apoptosis and necrosis. Higher ALT levels, therefore, usually reflect more vigorous immune response against HBV and more extensive hepatocyte damage [9]. This is eventually followed by $\mathrm{HBeAg}$ seroconversion to its antibody (anti-HBe) and/or undetectable HBV-DNA. The estimated annual incidence of spontaneous $\mathrm{HBeAg}$ seroconversion was $2-15 \%$, depending on factors such as age, ALT levels, and HBV genotype [9, 10]. Some patients may experience only transient and mild elevation of serum ALT levels before $\mathrm{HBeAg}$ seroconversion [11]. $\mathrm{HBeAg}$ 
Table 1 Definition of frequently used terminology

\begin{tabular}{|c|c|}
\hline Terminology & Definition \\
\hline \multicolumn{2}{|l|}{ Alanine aminotransferase (ALT) } \\
\hline High normal & Serum ALT levels between 0.5 and 1 times upper limit of normal reference (ULN). \\
\hline Low normal & Serum ALT $\leq 0.5$ times ULN \\
\hline Minimally raised & Serum ALT levels between 1 and 2 times ULN \\
\hline Biochemical response & Normalization of serum ALT levels \\
\hline Chronic HBV infection & HBsAg seropositive $\geq 6$ months \\
\hline Clinical breakthrough & Virologic breakthrough with increased ALT levels or worsening histology \\
\hline \multicolumn{2}{|l|}{ Drug resistance } \\
\hline Genotypic resistance & $\begin{array}{l}\text { Detection of mutations in the HBV genome, known to confer resistance, which develop during } \\
\text { antiviral therapy }\end{array}$ \\
\hline Phenotypic resistance & $\begin{array}{l}\text { Decreased susceptibility (in vitro testing) to inhibition by antiviral drugs associated with } \\
\text { genotypic resistance }\end{array}$ \\
\hline Cross resistance & Mutation selected by one antiviral agent that also confers resistance to other antiviral agents \\
\hline Hepatic decompensation & $\begin{array}{l}\text { Significant liver function abnormality as indicated by raised serum bilirubin level and } \\
\text { prolonged prothrombin time or occurrence of complications such as ascites }\end{array}$ \\
\hline Hepatitis flare & Increase of serum ALT level to $\geq 5$ times ULN \\
\hline Inactive chronic $\mathrm{HBV}$ infection & $\begin{array}{l}\text { HBsAg }(+) \text { anti-HBe }(+) \text { with persistent normal serum ALT and HBV-DNA }<2,000 \mathrm{IU} / \mathrm{ml} \\
\left(10^{4} \text { copies } / \mathrm{ml}\right)\end{array}$ \\
\hline Undetectable serum HBV-DNA & Serum HBV-DNA levels below detection limit of a PCR-based assay \\
\hline \multicolumn{2}{|l|}{ Virological response } \\
\hline Maintained virologic response & Undetectable serum HBV-DNA and $\mathrm{HBeAg}$ seroconversion, if applicable, during therapy \\
\hline Primary treatment failure & $\begin{array}{l}\text { Reduction of serum HBV-DNA }<1 \log \mathrm{IU} / \mathrm{ml} \text { at } 12 \text { weeks of oral antiviral therapy } \\
\text { in a compliant patient }\end{array}$ \\
\hline Viral breakthrough & $\begin{array}{l}>1 \log \mathrm{IU} / \mathrm{ml} \text { increase in serum HBV-DNA from nadir of initial response during therapy } \\
\text { as confirmed } 1 \text { month later }\end{array}$ \\
\hline Secondary treatment failure & Viral breakthrough in a compliant patient (due to drug resistance) \\
\hline Sustained virologic response & $\begin{array}{l}\text { Serum HBV-DNA }<2,000 \mathrm{IU} / \mathrm{ml}\left(10^{4} \text { copies } / \mathrm{ml}\right) \text { and } \mathrm{HBeAg} \text { seroconversion, if applicable, } \\
\text { for at least } 6 \text { months after stopping therapy }\end{array}$ \\
\hline Complete response & Sustained virologic response with HBsAg seroclearance \\
\hline
\end{tabular}

seroconversion is followed by clinical remission (inactive chronic HBV infection) in the majority of patients. However, active hepatitis may relapse due to $\mathrm{HBeAg}$ seroreversion or occurrence of HBeAg-negative hepatitis. The estimated annual incidence of hepatitis relapse was $2.2-3.3 \%[11,12]$, being higher in males, genotypes $\mathrm{C}$ infected, and those who have $\mathrm{HBeAg}$ seroconversion after age 40 [13]. A recent long-term follow-up study (mean $=12.3$ years) involving 1,241 incidentally identified subjects with inactive chronic HBV infection showed a lower annual incidence of $1.5 \%$, being significantly much lower in younger patients, especially those younger than 30 years [11]. All these findings suggest that earlier $\mathrm{HBeAg}$ seroconversion or shorter HBeAg-positive phase is associated with higher chance of sustained remission. Asymptomatic HBeAg-negative subjects with HBVDNA $>2,000 \mathrm{IU} / \mathrm{ml}$ may also experience hepatitis flares and disease progression such as in $\mathrm{HBeAg}$-positive patients [10-15]. Since the immunopathogenesis of HBeAg-negative hepatitis is similar to that of $\mathrm{HBeAg}$-positive hepatitis, this phase can be viewed as a variant of immune clearance phase.

A prospective study involving 684 patients with chronic HBV infection showed that cirrhosis developed at an estimated annual incidence of $2.1 \%$, and that age, the extent, severity, frequency of flares, and the duration of hepatic lobular alterations were factors for disease outcomes and HBV clearance [16]. Patients with chronic HBV infection with persistent $\mathrm{HBeAg}$ seropositivity have an even higher incidence (3.5\% per year) of cirrhosis [17]. One study showed that $23 \%$ of the patients with $\mathrm{HBeAg}$ negative hepatitis progressed to cirrhosis during a followup period of 9 years (range $=1-18.4$ ) [12]. A recent Korean long-term follow-up study (mean $=120$ months) involving 188 patients (52 HBeAg-negative patients) showed that age and persistent ALT elevation are independent factors for the development of cirrhosis, decompensation, and hepatocellular carcinoma (HCC) [18]. HCC develops at an annual incidence of 3-6\% in patients with cirrhosis and far less frequently in 
noncirrhotic patients $[12,19,20]$. Seropositivity for $\mathrm{HBeAg}$ and/or HBV-DNA > 2,000 IU/ml are significant risk factors for cirrhosis and HCC development, even in asymptomatic subjects with chronic HBV infection [2125].

Spontaneous HBsAg seroclearance may occur after HBeAg seroconversion. A recent 11-year follow-up study in 1,965 asymptomatic anti-HBe positive subjects [age $=16-76$ years $($ median $=34)]$ showed an annual HBsAg seroclearance rate of $1.2 \%$. The cumulative HBsAg seroclearance rate was $8 \%$ at 10 years, increased disproportionately to $25 \%$ at 20 years, and $45 \%$ at 25 years of follow-up [26] HBsAg seroclearance usually confers excellent prognosis [27]. However, HCC may still occur, although at a very low rate if cirrhosis has already developed before HBsAg seroclearance [27, 28].

Hepatitis B virus has been classified into at least eight genotypes on the basis of an intergroup divergence of $8 \%$ or more in the complete genome nucleotide sequence. Subtypes are identified within some genotypes, but their clinical significance remains to be determined. Each genotype has its distinct geographical and ethnic distribution, worldwide and within the Asian-Pacific region. HBV genotypes $\mathrm{B}$ and $\mathrm{C}$ are prevalent in East and South-East Asia, the Pacific Islands, and Pakistan, whereas HBV genotypes $\mathrm{D}$ and $\mathrm{A}$ are prevalent in India and genotype $\mathrm{A}$ in the Philippines. HBV genotype $\mathrm{D}$ is also found in the Pacific Islands. HBV genotypes B and C are prevalent in highly endemic areas where perinatal or vertical transmission plays an important role in spreading the virus, whereas genotypes A, D, E, F, and G are frequently found in areas where the main mode of transmission is horizontal. The clinical significance and virologic characteristics of HBV genotypes have only been reliably compared between genotypes B and C or genotypes A and D. In general, genotype $\mathrm{B}$ is associated with less progressive liver disease than genotype $\mathrm{C}$, and genotype $\mathrm{D}$ has a less favorable prognosis than genotype A [29]. A recent study in 1,536 Alaskan natives with chronic HBV infection has shown that the median age for $\mathrm{HBeAg}$ clearance was less than 20 years for genotypes A, B, D, and F, but more than 40 years for genotype $C$, and that patients with genotypes $\mathrm{C}$ and $\mathrm{F}$ have significantly more frequent $\mathrm{HBeAg}$ reversion and higher risk of HCC [30]. Several studies have shown that genotype B is associated with spontaneous $\mathrm{HBeAg}$ seroconversion at a younger age, less active liver disease, slower progression to cirrhosis, and less frequent development of HCC than genotype C [10, 22, 29-34]. HBV genotype $B$ has been shown to induce a greater $\mathrm{Th}_{1}$ and lesser $\mathrm{Th}_{2}$ response than genotype $\mathrm{C}$, leading to a higher chance of HBeAg seroconversion [35]. A study from India indicated that genotype $\mathrm{D}$ is more often associated with HBeAg-negative chronic HBV infection and more severe diseases and may predict the occurrence of $\mathrm{HCC}$ in young patients [36]. It has also been shown that recombinant genotypes lead to more severe disease.

Due to the spontaneous error rate of viral reverse transcription, naturally occurring HBV mutations arise during the course of infection under the pressure of host immunity or specific therapy. Several HBV strains including mutations in precore, core promoter, and deletion mutation in pre-S/S genes have been reported to be associated with the pathogenesis of fulminant or progressive liver disease, including cirrhosis and HCC [29]. Patients harboring HBV genotype $\mathrm{C}$ have a higher HBV-DNA level, higher frequency of pre-S deletions, higher prevalence of core promoter A1762T and/or G1768/A mutations, and A1762T/G1764A double mutations than patients infected with HBV genotype $\mathrm{B}$ and have a significantly higher chance of developing HCC $[21,25,29,34,37,38]$. A recent study revealed that a complex mutation pattern rather than a single mutation was associated with disease progression [38]. The role of these naturally occurring HBV mutations in the pathogenesis of liver disease progression requires further studies.

Concurrent infection with other virus(es)

Hepatitis B virus, hepatitis C virus (HCV), hepatitis delta virus (HDV), and human immunodeficiency virus (HIV) share similar transmission routes. Therefore, concurrent infection with these viruses may occur and complicate the natural course of chronic HBV infection. In general, concurrent infection with these viruses usually results in more severe and progressive liver disease and thus needs treatment [39].

\section{Goals of treatment for chronic HBV infection}

It is now clear that active HBV replication is the key driver of liver injury and disease progression, thus sustained viral suppression is of paramount importance [40]. Therefore, the primary aim of treatment for chronic HBV infection is to permanently suppress HBV replication. This decreases infectivity and pathogenicity of the virus. Reducing the pathogenicity of the virus results in reduced hepatic necroinflammation. Clinically, the short-term goal of treatment is to achieve "initial response" in terms of HBeAg seroconversion and/or HBV-DNA suppression, ALT normalization, and prevention of hepatic decompensation; to ensure "maintained/sustained response" to reduce hepatic necroinflammation and fibrosis during/after therapy. The ultimate long-term goal of therapy is to achieve "durable response" to prevent hepatic decompensation, reduce or prevent progression to cirrhosis and/or HCC, and prolong survival. 
Currently available treatments

Currently, IFN- $\alpha$, lamivudine, adefovir, entecavir, telbivudine, and PegIFN- $\alpha 2$ a have been licensed globally. Clevudine has been approved in Korea. Thymosin $\alpha_{1}$ has also been approved in many countries in Asia.

\section{IFN-based therapy}

Conventional IFN Conventional IFN- $\alpha$ has been used for the treatment of chronic HBV infection for more than two decades. IFN $-\alpha$ has a dual mode of action: antiviral and immunomodulatory. Early controlled studies have shown that a 4- to 6-month course of conventional IFN- $\alpha$ at a dose of $5 \mathrm{MU}$ daily or $10 \mathrm{MU} 3$ times weekly achieved $\mathrm{HBeAg}$ loss in approximately $33 \%$ of $\mathrm{HBeAg}$-positive patients in comparison with $12 \%$ of controls. Smaller dosage (5-6 MU 3 times weekly) has been used in Asian patients with similar efficacy. Treatment of longer than 12 months'duration may improve the rate of $\mathrm{HBeAg}$ seroconversion, particularly in those with lower HBV-DNA levels after 16 weeks of treatment. Retreatment of relapsed patients with IFN- $\alpha$ showed a response rate of $20-40 \%$. When $\mathrm{HBeAg}$ seroconversion to anti-HBe is achieved, it is sustained in more than $80 \%$ of cases [41].

Children with chronic HBV infection and high ALT levels respond to IFN $\alpha$ at rates similar to adults. A recent study involving 108 Italian children, however, showed that there was no significant difference in the overall long-term outcomes in IFN- $\alpha$-treated and untreated patients, and no patient developed end-stage liver disease or HCC during 12 years (range $=5-23$ ) of follow-up [42].

The HBeAg seroconversion rate is lower in patients with lower baseline ALT levels. This rate may be improved by corticosteroid priming before IFN therapy. The recovery of immune function following steroid withdrawal may result in ALT flares and enhance the effect of IFN. A metaanalysis involving 790 patients in 13 randomized trials showed that this approach was associated with significantly more frequent loss of $\mathrm{HBeAg}(P=0.03)$ and HBV-DNA $(P=0.0008)$, particularly in Asian patients with lower ALT levels and when lower dose of corticosteroid was used [43]. Severe adverse effects have been reported with this approach in patients with advanced liver disease.

IFN- $\alpha$ therapy resulted in end-of-treatment biochemical and virological response in up to $90 \%$ of patients with HBeAg-negative hepatitis. Sustained response rates, however, were disappointing: $10-15 \%$ with $4-6$ months of treatment; $22 \%$ with 12 months of treatment; and $30 \%$ with 24 months of treatment. A study from Taiwan showed that 6-10 months' IFN therapy in HBeAg-negative patients had an end-of-treatment response of $57 \%$ (vs. $18 \%$ of controls) and 6 months' sustained response of 30\% (vs. 7\%).
Long-term follow-up studies suggest that IFN-induced $\mathrm{HBeAg}$ seroconversion is durable, increases over time, results in less cirrhosis development [17], better overall survival, and survival free of hepatic decompensation [17, 44]. The incidence of HCC is also lower in treated patients, especially among responders [17, 40, 45]. High HBsAg loss rate observed after IFN- $\alpha$ therapy in Italian patients was not observed in Asian patients [17].

A meta-analysis involving 1,505 cirrhotic patients in seven trials favored IFN therapy in reducing HCC, although significant heterogeneity of the trials made these results less conclusive. However, it has been shown that IFN- $\alpha$ therapy in compensated cirrhotic patients is safe and even more effective than noncirrhotic patients [20]. This finding suggests that the benefit of IFN therapy in reducing HCC might be evident upon longer follow-up. A subgroup analysis in a recent long-term follow-up study did show that HCC incidence was reduced significantly in IFNtreated cirrhotic patients [17].

The main advantage of IFN- $\alpha$ therapy is that a course of finite duration may achieve sustained off-therapy response in a proportion of patients with both $\mathrm{HBeAg}$-positive and $\mathrm{HBeAg}$-negative chronic HBV infections. However, IFN treatment is usually associated with adverse effects, especially influenza-like symptoms, fatigue, neutropenia, thrombocytopenia, and depression. These are usually tolerable, but may require dose modification and premature cessation of treatment [41].

PegIFN- $\alpha$ In an Asian study, a 24-week course of weekly PegIFN- $\alpha 2 \mathrm{a}(40 \mathrm{kD})$ gave a higher HBeAg seroconversion $(33 \%$ vs. $25 \% ; P>0.05)$ and combination response (HBeAg loss, HBV-DNA $<5 \times 10^{5}$ copies $/ \mathrm{ml}$, and normal ALT) rate $(24 \%$ vs. $12 \% ; P=0.036)$ at 6 months after the end of treatment than conventional IFN- $\alpha 2 \mathrm{a}$. This benefit was noted even in patients with a rather low likelihood of response to conventional IFN [46]. In large-scale phase III international multicenter studies involving 814 HBeAg-positive patients ( $>85 \%$ were Asians) and 564 HBeAg-negative patients ( $>60 \%$ were Asians), PegIFN$\alpha 2 \mathrm{a} \quad(40 \mathrm{kD})$ monotherapy $180 \mu \mathrm{g}$ once weekly for 48 weeks resulted in ALT normalization in $41 \%$ and 59\% patients, HBV-DNA $<80 \mathrm{IU} / \mathrm{ml}(<400$ copies $/ \mathrm{ml})$ in $14 \%$ and $19 \%$ patients, and HBsAg seroclearance in $3 \%$ and $3 \%$ patients, respectively. $\mathrm{HBeAg}$ seroconversion occurred in $32 \%$ and HBV-DNA levels were less than $20,000 \mathrm{IU} / \mathrm{ml}$ $\left(<10^{5}\right.$ copies $\left./ \mathrm{ml}\right)$ in $32 \%$ of $\mathrm{HBeAg}$-positive patients, whereas HBV-DNA levels remained less than 4,000 IU/ml $\left(2 \times 10^{4}\right.$ copies $\left./ \mathrm{ml}\right)$ in $43 \%$ of $\mathrm{HBeAg-negative} \mathrm{patients}$ when assessed 6 months after cessation of therapy. PegIFN- $\alpha 2$ a was found to be superior to lamivudine, with respect to sustained $\mathrm{HBeAg}$ seroconversion and $\mathrm{HBV}$ DNA suppression, in both $\mathrm{HBeAg-positive} \mathrm{and}$ 
HBeAg-negative patients [47, 48]. These responses were sustained in up to $90 \%$ when assessed 3 years after end of therapy [49]. The 6 months' sustained HBeAg seroconversion rate is similar to that obtained after 6 months' therapy in an earlier phase II study. A 4-arm head-to-head randomized control study using 90 and $180 \mu \mathrm{g}$ of PegIFN$\alpha 2 \mathrm{a}$ for 6 or 12 months is ongoing.

Several studies using PegIFN- $\alpha 2 b$ showed similar efficacy [41]. One study showed that peg-IFN $\alpha 2 b$ was safe and effective in patients with advanced fibrosis or cirrhosis as those with early stage of fibrosis [50]. Patients with chronic HBV infection who are lamivudine refractory and those who are lamivudine naïve respond similarly to PegIFN- $\alpha 2 b$ therapy [51].

High baseline ALT, low baseline HBV-DNA and $\mathrm{HBeAg}$ levels, and high-grade necroinflammatory activity are predictors of response to IFN and PegIFN- $\alpha$ therapy [41]. ALT flares followed by decrease in HBV-DNA levels and decline of HBeAg levels during PegIFN- $\alpha$ therapy were predictors of response at the end of follow-up [52, 53]. Baseline ALT, baseline HBV-DNA, and HBV genotype influence the combined response (ALT normalization and $\mathrm{HBV}$-DNA $<4 \times 10^{3} \mathrm{IU} / \mathrm{ml}\left[<2 \times 10^{4}\right.$ copies $\left./ \mathrm{ml}\right]$ ) at 24 weeks posttreatment in patients with $\mathrm{HBeAg-nega-}$ tive chronic HBV infection with a 48-week course of PegIFN- $\alpha 2 \mathrm{a}$ with or without lamivudine [54].

Studies using conventional IFN therapy have shown that patients with $\mathrm{HBV}$ genotypes $\mathrm{A}$ and $\mathrm{B}$ infection have a higher $\mathrm{HBeAg}$ seroconversion rate than patients with $\mathrm{HBV}$ genotypes C and D infection, respectively [29]. These findings were confirmed by recent studies using PegIFN, where $\mathrm{HBeAg}$ seroconversion occurred more often in patients with HBV genotypes A $(40 \%-47 \%)$ and B $(30 \%-$ $44 \%)$ than those with HBV genotypes C (28\%-30\%) and D $(20 \%-25 \%)$ infection $[46,55]$. Significantly better response in genotype B infected patients (31\% vs. $17.5 \%$ of genotype $\mathrm{C}$ infected; $P<0.05$ ) was observed in earlier 6-month PegIFN- $\alpha 2$ a trial [46] but not in the recent 12-month trial [47]. This may suggest that longer PegIFN therapy may be required to enhance the response of the patients with more difficult-to-treat situations such as in genotype $\mathrm{C}$ or $\mathrm{D}$ infected patients.

IFN combination with other agents Studies using IFN- $\alpha$ or PegIFN- $\alpha$ and lamivudine combination in comparison with IFN- $\alpha$ or PegIFN- $\alpha$ or lamivudine monotherapy in $\mathrm{HBe} A g$-positive and $\mathrm{HBeAg-negative} \mathrm{patients} \mathrm{showed} \mathrm{that}$ combination therapy had greater on-treatment viral suppression and higher rates of sustained response than lamivudine monotherapy, but there was no difference in sustained off-treatment response when compared with IFN$\alpha$ or PegIFN- $\alpha$ monotherapy [47, 48]. To date, there has been no large clinical trial that confirms the benefits of
PegIFN- $\alpha$ plus nucleoside or nucleotide analogue therapy over PegIFN- $\alpha$ monotherapy [41].

Sequential therapy with lamivudine $100 \mathrm{mg}$ daily for 4 weeks followed by PegIFN- $\alpha 2 \mathrm{~b} 1.0 \mu \mathrm{g} / \mathrm{kg}$ per week for a further 24 weeks ( $n=36$ patients) compared with PegIFN- $\alpha 2 b$ monotherapy for 24 weeks ( $n=27$ patients) in patients with HBeAg-positive chronic HBV infection showed a significantly higher rate of HBV-DNA undetectability $(<4,700$ copies/ml) $(50 \%$ vs. $14.8 \%)$ and higher rates of $\mathrm{HBeAg}$ clearance $(38.9 \%$ vs. $14.8 \%)$ at 6 months posttherapy [56].

A randomized controlled trial in 96 patients showed that lymphoblastoid IFN $5 \mathrm{MU}$ in combination with thymosin $\alpha-11.6 \mathrm{mg} 3$ times weekly for 24 weeks increased $\mathrm{HBeAg}$ loss 1 year after the end of treatment with marginal significance in comparison with IFN monotherapy (45.8\% vs. 28\%; $P=0.067$ ) [57].

IFN-based therapy: overall conclusions The advantages of IFN-based therapy include finite duration of treatment with modest response, long-term benefit, and no resistance. PegIFN may eventually replace conventional IFN because of higher efficacy and more convenient once weekly administration. The optimal duration (6 vs. 12 months) of PegIFN therapy in HBeAg-positive patients is under study. Perhaps patients infected with HBV genotype $\mathrm{C}$ or D may require longer treatment.

\section{Other immunomodulating agents}

Thymosin $\alpha-1 \quad$ A few studies have evaluated the efficacy of thymosin $\alpha-1\left(\mathrm{~T} \alpha_{1}\right)$, an immunomodulating agent that enhances the $\mathrm{Th}_{1}$ immune response, natural killer $\mathrm{T}$ cells, and $\mathrm{CD}^{+} \mathrm{CTL}$ activity against HBV. A Taiwanese study showed that therapy with subcutaneous $\mathrm{T} \alpha_{1} 1.6 \mathrm{mg}$ twice weekly for 6 months resulted in a significantly higher $\mathrm{HBeAg}$ seroconversion rate (40\% vs. $9 \%$ in controls) when assessed 12 months after the end of therapy [58]. A 6-month therapy in Chinese $\mathrm{HBeAg}$-negative patients also showed a response rate of $42 \%$ (11/26) [59]. Patients infected with genotype B HBV showed a significantly better response $(52 \%)$ than patients infected with genotype C $(24 \%) \mathrm{HBV}$ [60]. A response rate of $22 \%$ was also observed in a Japanese study involving 316 patients, mostly infected with genotype C HBV [61]. A meta-analysis including 353 patients from five trials showed that the odds ratio for virological response to $\mathrm{T} \alpha_{1}$ at the end of treatment, 6 , and 12 months posttreatment were $0.56(0.2-$ 1.52), 1.67 (0.83-3.37), and 2.67 (1.25-5.68), respectively, with a significantly increasing virological response over time after discontinuation of thymosin therapy [62]. The number of patients included in thymosin $\alpha-1$ trials was relatively small in comparison with recent trials using 
PegIFN or nucleoside analogues. More well-designed, large-scale studies are needed to confirm its efficacy. The main advantages of thymosin $\alpha-1$ are fixed duration of therapy and minimal side effects.

Therapeutic vaccines Various therapeutic vaccines were used in an attempt to restore the virus-specific host immune response. However, none of them demonstrated sufficient clinical efficacy. In a recent open-label controlled study, 195 HBeAg-positive patients were randomized to receive 12 doses of $\mathrm{HBsAg}$ with AS02 adjuvant candidate vaccine plus lamivudine daily for 52 weeks or lamivudine daily alone. Despite induction of a vigorous HBsAg-specific lymphoproliferative response, cytokine production, and anti-HBs antibodies, therapeutic vaccination with an adjuvanted HBsAg vaccine combined with lamivudine did not demonstrate superior clinical efficacy than lamivudine alone [63].

\section{Direct antiviral agents}

Lamivudine, adefovir, entecavir, and telbivudine are highly effective in inhibiting HBV replication and have been approved worldwide for the treatment of chronic HBV infection. These agents are prodrugs and need intracellular activation before they can exert their therapeutic action.
The efficacy of treatment with these four drugs is compared in Table 2. Clevudine has been approved only in Korea. Tenofovir and other new nucleoside analogues are in various stages of appraisal.

Lamivudine Lamivudine, an L-nucleoside analogue, at a daily dose of $100 \mathrm{mg}$ is effective in suppressing HBVDNA with ALT normalization and histologic improvement in both HBeAg-positive and HBeAg-negative patients [64]. $\mathrm{HBeAg}$ seroconversion is achieved in $35-65 \%$ of $\mathrm{HBeAg}$ positive patients after 5 years of therapy; the rate being proportional to the levels of ALT prior to treatment and highest in patients with ALT levels over 5 times ULN. This suggests that patients with a more vigorous immune response to $\mathrm{HBV}$ respond better to the direct antiviral effect of lamivudine [65]. The $\mathrm{HBeAg}$ seroconversion rate is similar in patients with HBV genotype B or C infection. Children treated with lamivudine for 1 year with dosages adjusted for body weight $(3 \mathrm{mg} / \mathrm{kg})$ showed similar response to adults, and the drug has been found to be safe during 3 years of continuous therapy [66]. In the absence of $\mathrm{HBeAg}$ seroconversion, hepatitis flares may occur if lamivudine is stopped. Lamivudine can be stopped after $\mathrm{HBeAg}$ seroconversion. Sustained HBeAg seroconversion to anti-HBe occurs in $\sim 80 \%$ of patients after cessation of lamivudine therapy [64]. The durability of response is
Table 2 Comparisons of viral responses among four antiviral agents in treatment-naïve patients with chronic hepatitis B

\begin{tabular}{|c|c|c|c|c|c|c|c|c|}
\hline & \multicolumn{2}{|c|}{ Lamivudine } & \multicolumn{2}{|c|}{ Adefovir dipivoxil } & \multicolumn{2}{|c|}{ Entecavir } & \multicolumn{2}{|c|}{ Telbivudine } \\
\hline & $\mathrm{e}(+)$ & $\mathrm{e}(-)$ & $\mathrm{e}(+)$ & $\mathrm{e}(-)$ & $\mathrm{e}(+)$ & $\mathrm{e}(-)$ & $\mathrm{e}(+)$ & $\mathrm{e}(-)$ \\
\hline \multicolumn{9}{|c|}{ HBV-DNA (-log) } \\
\hline Year 1 & $\begin{array}{l}5.4^{\mathrm{a}} \\
5.4^{\mathrm{c}}\end{array}$ & $\begin{array}{l}4.5^{\mathrm{b}} \\
4.1^{\mathrm{c}}\end{array}$ & $\begin{array}{l}3.6 \\
{[1.0]}\end{array}$ & $\begin{array}{l}3.7 \\
{[1.4]}\end{array}$ & $6.9^{\mathrm{a}}$ & $5.0^{\mathrm{b}}$ & $5.7^{\mathrm{c}}$ & $4.4^{\mathrm{c}}$ \\
\hline \multicolumn{9}{|c|}{ Undetectable } \\
\hline Year 1 & $\begin{array}{l}36 \%^{\mathrm{a}} \\
40 \%^{\mathrm{c}}\end{array}$ & $\begin{array}{l}72 \%^{b} \\
71 \%^{c}\end{array}$ & $\begin{array}{l}21 \% \\
{[0 \%]}\end{array}$ & $\begin{array}{l}61 \% \\
{[0 \%]}\end{array}$ & $67 \%^{\mathrm{a}}$ & $90 \% \mathrm{~b}$ & $60 \%{ }^{\mathrm{c}}$ & $88 \%^{\mathrm{c}}$ \\
\hline Year 2 & $\begin{array}{l}39 \% *^{\mathrm{d}} \\
39 \%^{\mathrm{c}}\end{array}$ & $\begin{array}{l}\text { NA } \\
57 \%^{\mathrm{c}}\end{array}$ & NA & $71 \%$ & $80 \% * \mathrm{~d}$ & NA & $56 \%^{\mathrm{c}}$ & $82 \%{ }^{\mathrm{c}}$ \\
\hline Year 3 & $20 \%$ & $40 \%$ & NA & $77 \% * *$ & $89 \% *$ & NA & NA & NA \\
\hline \multicolumn{9}{|c|}{$\mathrm{HBe} A g$ seroconversion } \\
\hline Year 1 & $\begin{array}{l}18 \%^{\mathrm{a}} \\
22 \%^{\mathrm{c}}\end{array}$ & NA & $\begin{array}{l}12 \% \\
{[6 \%]}\end{array}$ & NA & $21 \%^{\mathrm{a}}$ & NA & $23 \%^{\mathrm{c}}$ & NA \\
\hline Year 2 & $\begin{array}{l}26 \% * \\
25 \%\end{array}$ & NA & $29 \%$ & NA & $31 \% *$ & NA & $30 \%{ }^{\mathrm{e}}$ & NA \\
\hline Year 3 & $40 \%$ & NA & NA & NA & NA & NA & NA & NA \\
\hline \multicolumn{9}{|c|}{ Genotypic resistance } \\
\hline Year 1 & $\begin{array}{l}13 \%^{\mathrm{a}} \\
11 \%^{\mathrm{c}}\end{array}$ & $\begin{array}{l}6 \%^{\mathrm{b}} \\
11 \%^{\mathrm{c}}\end{array}$ & $0 \%$ & $0 \% *$ & $0 \%^{\mathrm{a}}$ & $0 \%^{\mathrm{b}}$ & $5 \%^{\mathrm{c}}$ & $2 \%^{\mathrm{c}}$ \\
\hline Year 2 & $\begin{array}{l}38 \%^{\mathrm{d}} \\
40 \%^{\mathrm{e}}\end{array}$ & $\begin{array}{l}31 \% \\
26 \%\end{array}$ & NA & $3 \% *$ & $0 \%^{\mathrm{d}}$ & NA & $25 \%{ }^{\mathrm{e}}$ & $11 \%^{\mathrm{e}}$ \\
\hline Year 3 & $57 \%$ & $57 \%$ & NA & $11 \% *$ & $\sim 1 \%$ & NA & NA & NA \\
\hline
\end{tabular}


particularly low in patients with genotype C HBV infection, older patients, and if treatment is maintained for less than 4-8 months after $\mathrm{HBeAg}$ seroconversion [67]. Acute flares of hepatitis may occur in patients with the reappearance of $\mathrm{HBeAg}$ and detectable HBV-DNA (HBeAg seroreversion). In pediatric patients, the durability of $\mathrm{HBeAg}$ seroconversion increased from $82 \%$ to more than $90 \%$ in those who had received lamivudine for 52 weeks and more than 2 years, respectively [66].

The antiviral and therapeutic impact of lamivudine in patients with $\mathrm{HBeAg}$-negative chronic $\mathrm{HBV}$ infection is similar to that in HBeAg-positive patients. Sustained antiviral response is obtained in only $15-20 \%$ of cases after 1 year of treatment [63]. Lamivudine therapy for 612 months resulted in $81 \%$ maintained virologic response in a study involving 85 Taiwanese HBeAg-negative patients with pretreatment ALT $>5$ times ULN, and sustained virologic response was observed in $39 \%$ of these patients 12 months after stopping lamivudine therapy [68]. In a study involving 50 Chinese-Canadian patients, 2-year treatment with lamivudine resulted in maintained virologic response in 37 (74\%) patients. Therapy was stopped in these 37 patients when undetectable HBV-DNA and normal ALT levels were documented on three separate occasions at least 3 months apart. Relapse was noted in $50 \%$ of these patients ( $86 \%$ of them infected with genotype C HBV) 1 year after cessation of therapy [69]. In a Hong Kong Chinese study, 2-year lamivudine treatment in 89 HBeAg-negative patients showed a maintained complete response (normal ALT and HBV-DNA $<2 \times 10^{3} \mathrm{IU} / \mathrm{ml}$ $\left[<10^{4}\right.$ copies $\left.\left./ \mathrm{ml}\right]\right)$ rate of $56 \%$ and a sustained response rate of $26 \% 6$ months posttherapy [70]. These three studies show that about $50 \%$ of the patients who achieved maintained response have sustained off-therapy response.

Lamivudine is well tolerated and is safe for use, even in patients with decompensated cirrhosis [20, 64]. Long-term therapy in viremic patients with advanced fibrosis or cirrhosis delays clinical progression by reducing the rate of hepatic decompensation and HCC development, even in patients with low or normal ALT levels [71].

After 6-9 months of lamivudine therapy, viral breakthrough may occur following the emergence of HBV mutations that are resistant to lamivudine. These HBVvariant species have mutations in the YMDD motif of the polymerase gene (rtM204I and rtM204V with or without $\mathrm{rtL} 180 \mathrm{M})$. The incidence increases with increasing duration of therapy, up to $70 \%$ among patients treated with lamivudine continuously for 5 years. Other factors associated with the emergence of rtM204 I/V include baseline HBV-DNA, ALT, and/or hepatitis activity, sex and body mass index, and initial virologic response. Recent studies have shown that detectable HBV-DNA at month 6 was associated with higher resistance rate $[64,70]$. The emergence of genotypic resistance is usually followed by a more than $1 \log$ increase of HBV-DNA from nadir (viral breakthrough). With continuation of therapy, ALT elevation (biochemical breakthrough) occurs in more than $90 \%$ of patients after documented viral breakthrough [72, 73]. Hepatitis flares may develop and can occasionally result in hepatic decompensation [74]. New and distinct mutants may be selected during continuing lamivudine therapy and elicit further hepatitis flares [75]. The initial histologic improvement may be reversed in patients with $\mathrm{rtM} 204 \mathrm{I} / \mathrm{V}$ [76]. The benefit of long-term therapy in preventing disease progression in patients with advanced fibrosis or cirrhosis also decreased after emergence of rtM204 I/V [71, 77]. The decision on long-term lamivudine therapy must therefore take into consideration the potential clinical benefits, possible risk associated with drug-resistant mutations, and the durability of response after stopping therapy.

Combination therapy using lamivudine with adefovir, telbivudine, IFN, or PegIFN has not demonstrated significant efficacy advantage in controlled trials. These combinations, however, lower the rates of resistant mutations than lamivudine monotherapy [64]. A pilot study in 30 Taiwanese patients showed that a short course of prednisolone priming enhanced $\mathrm{Th}_{1}$ response and efficacy subsequent to lamivudine therapy [78]. "Lamivudine pulse" therapy has resulted in sustained $\mathrm{HBeAg}$ and HBVDNA loss in $31 \%$ of 27 patients with chronic HBV infection and normal ALT levels [79]. This approach could be dangerous in patients with advanced fibrosis or cirrhosis.

Adefovir dipivoxil Adefovir dipivoxil is a synthetic acyclic adenine nucleotide analogue. It is a potent inhibitor of $\mathrm{HBV}$ reverse transcriptase in the wild-type $\mathrm{HBV}$ as well as in lamivudine-, telbivudine-, and entecavir-resistant mutants.

Two large international multicenter double-blinded, placebo-controlled studies have shown that oral adefovir dipivoxil $10 \mathrm{mg}$ daily for 48 weeks is effective in HBVDNA suppression, ALT normalization, and histologic improvement in patients with both $\mathrm{HBeAg}$-positive and $\mathrm{HBeAg}$-negative chronic $\mathrm{HBV}$ infections. In $\mathrm{HBeAg}-$ positive patients, $\mathrm{HBeAg}$ loss and $\mathrm{HBeAg}$ seroconversion increased from $12 \%$ (control 6\%) after 1 year to $40 \%$ after 3 years' therapy [64]. Up to 240 weeks of adefovir therapy in naïve $\mathrm{HBeAg-negative} \mathrm{patients} \mathrm{resulted} \mathrm{in} \mathrm{HBV}$ DNA $<200 \mathrm{IU} / \mathrm{ml}$ in $67 \%$ of patients, ALT normalization in $69 \%$ of patients, improvement in necroinflammation in $83 \%$ of patients, and regression of fibrosis in $73 \%$ of patients, respectively [80]. Response to adefovir was similar in Asian and Caucasian patients. Integrated analysis from all phase III clinical trials showed that HBV genotype does not influence virologic response to adefovir dipivoxil regardless of $\mathrm{HBeAg}$ serostatus [64]. 
The safety profile of $10 \mathrm{mg}$ of adefovir dipivoxil was similar to placebo in patients with compensated chronic HBV infection. Renal laboratory abnormalities reported with $30 \mathrm{mg}$ of adefovir dipivoxil were not observed with $10 \mathrm{mg}$ of dosage during the 1 -year study period. Reversible increase in serum creatinine of more than $0.5 \mathrm{mg} / \mathrm{dL}$ (maximum $1.5 \mathrm{mg} / \mathrm{dl}$ ) was reported in $3 \%$ of patients when therapy was extended to 5 years [80]. Most patients with decompensated chronic HBV infection, including patients with pre- and post-liver transplant, have some degree of underlying renal insufficiency. Studies on these patients showed increases in serum creatinine levels by $0.5 \mathrm{mg} / \mathrm{dl}$ or more from baseline in $16 \%$ of them by week $48,31 \%$ by week 96 , and $1 \%$ required discontinuation due to renal failure [64].

Sequenced RT domain of HBV-DNA polymerase identified rtN236T and rtA181T/V mutations with decreased susceptibility to adefovir dipivoxil in patients on adefovir therapy for more than 1 year. The overall incidence of adefovir-resistant mutation is low. Integrated incidence rate was $0 \%, 3 \%$, and $11 \%, 18 \%$, and $29 \%$ at the end of each successive year of therapy in $\mathrm{HBeAg}$-negative patients. $\mathrm{HBV}$-DNA > $200 \mathrm{IU} / \mathrm{ml}\left(10^{3}\right.$ copies $\left./ \mathrm{ml}\right)$ at week 48 were predictive of the emergence of adefovir-resistant mutations ( $49 \%$ vs. $6 \%$ of those $<10^{3}$ copies $/ \mathrm{ml}$ ) during 192 weeks of adefovir treatment [80]. Adefovir dipivoxil-resistant rtN236T mutant remains susceptible to L-nucleoside analogues lamivudine, emtricitabine, telbivudine, and entecavir in vitro and may argue for their combination in therapy. The $\mathrm{rtA} 181 \mathrm{~T} / \mathrm{V} \mathrm{HBV}$ is resistant to adefovir and all the L-nucleoside analogues, but sensitive to entecavir [73].

One year of adefovir dipivoxil monotherapy or in combination with lamivudine reduced serum HBV-DNA levels in most patients with lamivudine-resistant mutants (median reduction $=3.6 \log _{10}$ to $4.6 \log _{10}$ copies $/ \mathrm{ml}$ ). Switching to adefovir dipivoxil monotherapy in lamivudine-resistant patients appeared effective and safe, even in patients with liver decompensation [81]. The rate of resistant mutation, however, is higher under such circumstances (up to $30 \%$ by the end of year 2) than adefovir monotherapy in lamivudine-naïve patients [82]. A 3-year study of 145 lamivudine-resistant HBV-infected patients showed that add-on adefovir led to undetectable HBVDNA in $80 \%$ and normal ALT in $84 \%$ of patients, and none developed virologic and clinical breakthrough during 1274 months of therapy [83]. Add-on adefovir in patients with HBV-DNA $>10^{7}$ copies/ml is associated with insufficient virologic response [82, 84], and should therefore be instituted as soon as genotypic resistance is detected and before the serum HBV-DNA levels increase to a level too high to be suppressed successfully [85].

The high genetic barrier to resistance and the ability to suppress most lamivudine-resistant mutants (rtM204 V/I) makes adefovir dipivoxil an attractive drug. Renal toxicity is rare with the dose of $10 \mathrm{mg}$ and few patients had significant elevation of serum creatinine levels of more than $0.5 \mathrm{mg} / \mathrm{dl}$ in clinical studies. Caution must be exercised in treating patients with renal impairment.

Entecavir Entecavir is a cyclopentyl guanosine analogue with potent selective inhibition of the priming, DNAdependent synthesis, and reverse transcription functions of HBV polymerase. In a viral kinetic study comparing entecavir to adefovir in $\mathrm{HBeAg}$-positive patients with high viral load, entecavir showed significantly greater HBVDNA reduction as early as day $10, \mathrm{HBV}-\mathrm{DNA}$ reduction was $-6.23 \log$ versus $-4.42 \log$ at week 12 and $-7.28 \log$ vs. $-5.08 \log$ at week 48 , respectively [64]. Pivotal phase III randomized lamivudine controlled trials showed that 1-year entecavir $(0.5 \mathrm{mg} / \mathrm{day})$ is superior to lamivudine in reducing $\mathrm{HBV}$-DNA in both $\mathrm{HBeAg}$-positive (-6.9 log vs. $-5.4 \log ; P<0.0001 ; \mathrm{HBV}-\mathrm{DNA}<300$ copies $/ \mathrm{ml}$ in $67 \%$ vs. $36 \%$ ) [86] and $\mathrm{HBeAg-negative} \mathrm{patients}(-5.0 \mathrm{log}$ vs. $-4.5 \log ; P<0.001 ; \mathrm{HBV}-\mathrm{DNA}<300 \mathrm{copies} / \mathrm{ml}$ in $90 \%$ vs. $72 \%$ ) [87]. HBeAg seroconversion rate was $21 \%$ (68\% in patients with pretherapy ALT $>5$ times ULN). Extending entecavir therapy to 96 weeks for partial responders at week 48 resulted in an increase in the rate of HBV-DNA $<60 \mathrm{IU} / \mathrm{ml}(<300$ copies/ml) to $74 \%$, ALT normalization increased to $79 \%$, and a cumulative $\mathrm{HBeAg}$ seroconversion rate of $31 \%$ [88]. The corresponding rate was $91 \%, 86 \%$, and additional $16 \%$, respectively, after extending entecavir therapy to 192 weeks [64].

Switching to entecavir monotherapy ( $1 \mathrm{mg} /$ day) is initially effective in lamivudine-resistant patients $(-5.11 \mathrm{log}$ vs. $-0.48 \log$ reduction in lamivudine controls; $P<0.001)$ and safe without risk of ALT flares. HBeAg loss was documented in $10 \%$ of lamivudine-resistant HBeAg-positive patients (vs. 3\% in lamivudine controls; $P=0.028$ ) [89]. Entecavir has a high genetic barrier, and drug resistance requires at least three mutations including rtL180M and rtM204 V, plus a mutation at one of the following codons: rtT184, rtS202, and/or rtM250 [73]. Therefore, entecavir therapy in lamivudine-refractory patients is associated with a higher entecavir resistance rate [88, 89]. The cumulative probability of a virologic breakthrough from entecavir resistance through 4 years is at least $0.8 \%$ in lamivudine-naïve patients and $39.5 \%$ in lamivudinerefractory patients $[64,73]$.

Telbivudine Telbivudine is an orally bioavailable L-nucleoside with potent and specific anti-HBV activity. In clinical trials, telbivudine gave more potent HBV suppression than lamivudine or adefovir. In the phase III randomized lamivudine controlled trial in 1,371 patients (446 HBeAg negative, 1,040 Asians), significantly greater 
HBV-DNA reduction with telbivudine $600 \mathrm{mg} /$ day was evident by week $12(-5.71 \log$ vs. $-5.42 \log$ in $\mathrm{HBeAg-}$ positive patients and $-4.36 \log$ vs. $-4.08 \mathrm{log}$ in $\mathrm{HBeAg}-$ negative patients). HBV-DNA reduction persisted through week 52 with greater histologic response, larger proportions of patients with undetectable HBV-DNA $(60.0 \%$ vs. $40.4 \%$ in $\mathrm{HBeAg}$-positive patients and $88.3 \%$ vs. $71.4 \%$ in HBeAg-negative patients), and less resistance $(5.0 \%$ vs. $11 \%$ in $\mathrm{HBeAg}$-positive patients and $2.3 \%$ vs. $10.7 \%$ in $\mathrm{HBeAg-negative} \mathrm{patients)} \mathrm{than} \mathrm{lamivudine.} \mathrm{The} \mathrm{C-domain}$ mutation rtM204I and the B-domain mutation rtA181T/V are the common mutations associated with telbivudine resistance. The HBeAg seroconversion rate was similar between telbivudine- and lamivudine-treated patients. The study also showed that $41 \%$ of $\mathrm{HBeAg}$-positive patients with undetectable HBV-DNA at week 24 underwent $\mathrm{HBeAg}$ seroconversion by week 52 versus $4 \%$ for patients with HBV-DNA $>2,000 \mathrm{IU} / \mathrm{ml}$ at week 24 . Only $1 \%$ of $\mathrm{HBeAg}$-positive patients with undetectable HBV-DNA and $2 \%$ of patients with HBV-DNA $<200 \mathrm{IU} / \mathrm{ml}\left(<10^{3}\right.$ copies/ $\mathrm{ml}$ ) at week 24 developed drug resistance by week 52 , whereas $11 \%$ of patients with HBV-DNA $>10^{4}$ copies $/ \mathrm{ml}$ at week 24 became resistant at week 52. The corresponding figures for drug resistance in $\mathrm{HBeAg}$-negative patients was $0 \%, 6 \%$, and $30 \%$, respectively [90]. Two-year telbivudine therapy was significantly superior to lamivudine in both $\mathrm{HBeAg}$-positive and $\mathrm{HBeAg}$-negative patients for all direct measures of antiviral effect, including serum HBV-DNA reduction from baseline ( -5.7 vs. -4.4 in $\mathrm{HBeAg}$-positive patients and -5.0 vs. -4.2 in $\mathrm{HBeAg}$-negative patients), PCR negativity $(56 \%$ vs. $39 \%$ in $\mathrm{HBeAg}$-positive patients and $82 \%$ vs. $57 \%$ in $\mathrm{HBeAg}$-negative patients), $\mathrm{HBeAg}$ seroconversion in patients with ALT $\geq 2$ times ULN $(36 \%$ vs. $27 \% ; P=0.022$ ), and viral resistance $(25 \%$ vs. $40 \%$ in $\mathrm{HBeAg}$-positive patients and $11 \%$ vs. $26 \%$ in $\mathrm{HBeAg}-$ negative patients; $P<0.001$ ). Week $24 \mathrm{HBV}$-DNA levels also emerged as a strong predictor of week 104 efficacy outcomes [64].

In another 1-year randomized adefovir controlled trial in $135 \mathrm{HBeAg}$-positive patients, significantly greater HBVDNA reduction with telbivudine was evident at week 24 ( $-6.30 \log$ vs. $-4.97 \mathrm{log}$, undetectable HBV-DNA in $39 \%$ vs. $12 \%$; $\geq 3 \log$ copies $/ \mathrm{ml}$ in $50 \%$ vs. $78 \%$ of patients) and week 52 (-6.56 log vs. -5.99 log; undetectable HBVDNA $60 \%$ vs. $40 \%$ of patients). The HBeAg seroconversion rate at week 52 of treatment was also higher in telbivudine-treated patients than in adefovir-treated patients ( $28 \%$ vs. $19 \% ; P=0.34)$. A predictive analysis of response showed that week 24 serum HBV-DNA $<200$ vs. $\geq 200 \mathrm{IU} / \mathrm{ml}$ (<3 $\log _{10}$ vs. $\geq 3 \log _{10}$ copies/ml) correlated with undetectable HBV-DNA (95\% vs. 24\%) and $\mathrm{HBeAg}$ seroconversion rate $(41 \%$ vs. $14 \%)$ at year 1.
Patients with viral breakthrough at year 1 had HBVDNA > $200 \mathrm{IU} / \mathrm{ml}\left(>3 \log _{10}\right.$ copies/ml) at week 24 [91].

Increase in creatine kinase levels was observed more frequently in recipients of telbivudine, of whom $7.5 \%$ (vs. $3.1 \%$ in lamivudine-treated controls) had grade 3 or 4 elevation (a level of $>7$ times ULN). Two-thirds of grade 3 or 4 creatine kinase elevations decreased spontaneously to grade 2 or lower during continued treatment. Symptomatic myopathy was reported in 1 patient after 11 months of telbivudine therapy, and resolved over a period of 912 months after stopping telbivudine [90].

Other emerging direct antivirals Clevudine is a pyrimidine analogue with potent and sustained antiviral activity against HBV. Clevudine $30 \mathrm{mg} /$ day for 24 weeks resulted in end-of-treatment HBV-DNA reduction of $5.10 \log _{10}$ copies/ml, undetectable HBV-DNA in 59\%, ALT normalization in $68.2 \%$, and $\mathrm{HBeAg}$ loss in $24 \%$ of $243 \mathrm{HBeAg}-$ positive patients [92]. The same regimen resulted in endof-therapy HBV-DNA reduction of $4.25 \log _{10}$ copies $/ \mathrm{ml}$, undetectable HBV-DNA in 92\%, and ALT normalization in $75 \%$ of $86 \mathrm{HBeAg-negative} \mathrm{patients;} \mathrm{HBV} \mathrm{suppression}$ sustained as HBV-DNA was $3.11 \log _{10}$ copies/ml, with undetectable HBV-DNA in $80.3 \%$ and normal ALT in $70.5 \%$ of patients 24 weeks after stopping clevudine [93]. No significant difference was reported in these efficacy parameters among the patients with different pretreatment ALT levels [92]. Substitutions rtA181A/T and rtA181T without viral breakthrough were detected in $5(2.7 \%)$ of the $182 \mathrm{HBeAg}$-positive patients [92], but none in $\mathrm{HBeAg}$ negative patients [93].

Tenofovir disoproxil fumarate is an acyclic adenine nucleotide that exerts a strong and early suppression of HBV with or without lamivudine-associated mutations. It has been approved for use in the treatment of HIV infection. Tenofovir $300 \mathrm{mg} /$ day is more potent than adefovir $10 \mathrm{mg} /$ day but without comparable renal toxicity. Clinical studies have shown that administration of tenofovir $300 \mathrm{mg}$ daily has stronger antiviral effect against lamivudineresistant HBV than adefovir $10 \mathrm{mg}$ daily [94, 95]. Phase III randomized adefovir controlled trial in $\mathrm{HBeAg-positive}$ patients has shown that tenofovir has better efficacy than adefovir with respect to histologic improvement (74\% vs. $68 \%$ ), HBV-DNA reduction to less than 400 copies $/ \mathrm{ml}$ (76\% vs. $13 \% ; P<0.001)$, ALT normalization $(69 \%$ vs. $54 \% ; P=0.02)$, and $\mathrm{HBeAg}$ seroconversion (21\% vs. $18 \% ; P=0.36)$. Tenofovir also achieved combined virologic and histologic response in a higher proportion of HBeAg-negative patients (71\% vs. 49\%; $P<0.001)$ [96]. Tenofovir appears to be a very promising drug and is likely to get approval for use in the treatment of chronic HBV infection and replace adefovir in the near future. 
Therapy with direct antiviral agent(s): overall conclusions The successive generation of nucleos(t)ide analogues has improved potency and raised genetic barrier to resistant mutations (Table 2). Although there is no headto-head comparison among these 4 drugs, the results of published pivotal trials suggest that entecavir is the most potent agent, followed by telbivudine, lamivudine, and adefovir in terms of HBV-DNA reduction during a 1-year treatment period. Histologic improvement and documented regression of advanced fibrosis and cirrhosis among the responders is an important achievement. Reduction in the progression of disease and HCC development after 3 years of lamivudine therapy for patients with advanced fibrosis is a proof for therapeutic aim. Increased antiviral potency of these drugs, however, does not correlate with increase in $\mathrm{HBeAg}$ loss or $\mathrm{HBeAg}$ seroconversion. Resistance is a major concern during long-term therapy. The incidence at 1 and 2 years is highest with lamivudine, followed by telbivudine, then adefovir and tenofovir, and almost none with entecavir. In choosing a direct antiviral agent to initiate therapy, resistance profile is a crucial factor to consider other than the potency and cost. The "roadmap" concept for using on-treatment HBV-DNA level as a predictor for drug resistance may be useful when patients are treated with agents with high resistance rate [97]. Pharmacoeconomic studies would be helpful in individual countries in Asia-Pacific region because cost is one of the most important factors in the choice of drug for initial therapy [98].

Special groups of patients

\section{Pregnancy}

IFN-based therapy is contraindicated in pregnancy because of its antiproliferative effect. Among the direct antiviral agents, telbivudine is classified as category B drug (no risk in animal studies, but unknown in human), whereas lamivudine, adefovir and entecavir are classified as category $\mathrm{C}$ drugs (teratogenic in animal, but unknown in human) by the US FDA [99]. The stage of the mother's liver disease and potential benefit of treatment must be weighed against the small risk to the fetus. IFN-based therapy is preferable in women in the childbearing age, and pregnancy is discouraged during IFN therapy. No firm recommendation can be made on the use of nucleosi $(t) d e$ analogues in the prevention of transmission from viremic mothers because of the lack of sufficient data and conflicting results with regard to efficacy and adverse events. Women with chronic HBV infection who become pregnant while on direct antiviral therapy can continue treatment with category $\mathrm{B}$ drugs [3].
Patients with concurrent $H C V, H D V$, or HIV infection

Patients with concurrent HCV, HDV, or HIV infections tend to have a higher incidence of cirrhosis, HCC, and mortality. Insufficient data exist to reach firm conclusions on the management of patients with $\mathrm{HCV}$ and/or HDV infections. However, it is generally agreed that the dominant virus should be identified before designing therapeutic strategy. If HBV is dominant, treatment should be aimed toward this virus. If $\mathrm{HCV}$ is dominant, standard IFN or PegIFN therapy in combination with ribavirin can achieve a sustained HCV clearance rate comparable to that in $\mathrm{HCV}$ monoinfection. Lamivudine is ineffective in patients with chronic HDV infection. Small randomized controlled trials using 3-9 MU of IFN for 3-24 months showed a biochemical and virologic response in up to $70 \%$ of the patients with chronic HDV infection. Sustained response was noted in less than $20 \%$ of patients. Higher doses of IFN $-\alpha$ (9 MU thrice weekly) for 12 months have been found to inhibit HDV-RNA, normalize ALT, and improve histology in patients with chronic HDV infection. ALT response sustained in $50 \%$ of the patients and the long-term outcomes and survival improved significantly even in patients with liver cirrhosis [100]. IFN in combination with lamivudine therapy tends to increase response rate compared with IFN monotherapy [101]. Two small studies using weight-based PegIFN- $\alpha 2 \mathrm{~b}(1.5 \mu \mathrm{g} / \mathrm{kg}$ weekly) for 6 and 12 months, respectively, showed discrepant results [100].

In patients with concurrent HIV infection and $\mathrm{CD} 4^{+}$ counts of more than 500 cells $/ \mu \mathrm{L}$, treatment options include agents without anti-HIV activity: IFN, adefovir, and telbivudine. IFN-based therapy or adefovir is preferred because of the absence of resistance in the former and a low resistance profile in the later. Both lamivudine and tenofovir are active against HBV and HIV and can be used in combination as part of the highly active antiretroviral therapy (HAART) in patients who need both anti-HBV and anti-HIV therapies. In patients with low CD4 count and active liver disease, HBV should be treated first to avoid the risk of immune reconstitution syndrome that usually occurs with HIV treatment.

\section{Patients with hepatic decompensation}

Patients with hepatic decompensation should be considered for treatment because it may both improve their clinical status and even remove them from liver transplant lists. IFN does not benefit patients with Child's B or C cirrhosis. Moreover, significant adverse effects due to serious bacterial infections and possible exacerbation of liver disease occur even with low doses. Lamivudine is well tolerated and results in clinical improvement or stabilization, 
especially in patients who have completed a minimum of 6 months' treatment [102, 103]. Early treatment is recommended to improve outcomes. Selection of resistant mutants with resultant biochemical dysfunction, reduction in efficacy, and rapid clinical deterioration in this group of patients is a real concern with early treatment [20]. Adding adefovir to 128 lamivudine-resistant patients with decompensated cirrhosis and 196 lamivudine-resistant patients with recurrent $\mathrm{HBV}$ infection after liver transplantation was associated with 3-4 log reduction in serum HBV-DNA levels throughout the treatment period [104]. However, renal dysfunction is a potential problem in patients with hepatic decompensation. Close monitoring of renal function is, therefore, required if this drug is being used for such patients. Entecavir, telbivudine, and tenofovir are being evaluated as a primary treatment modality in patients with decompensated liver disease. Given the similar mechanisms of action and safety profile, the more potent entecavir, telbivudine, and tenofovir are anticipated to be more effective than or at least as effective as lamivudine in this clinical setting with lower or nearly no incidence of drug resistance and no problem with nephrotoxicity.

\section{Pediatric patients}

Children with elevated ALT levels respond to IFN and lamivudine in a similar manner to adults. A small study in children and adolescents (aged 2-17) showed that adefovir is generally well tolerated at a dose of $0.3 \mathrm{mg} / \mathrm{day}$ for those aged 2-11, and $10 \mathrm{mg}$ for those aged 12-17 [105]. Newer agents such as PegIFN and other nucleos(t)ide analogues have not yet been studied, but are likely to be as effective in children as in adults with chronic HBV infection. Longterm safety and drug resistance are more important concerns in children than in adults. As already mentioned, recent long-term follow-up study showed that IFN therapy provided little benefit in comparison with untreated children [42]. Therefore, drug therapy is usually not recommended in pediatric patients because of the apparent lack of long-term benefits and attending risks of starting drug therapy, unless there is an absolute indication such as in the setting of ensuing or overt hepatic decompensation.

\section{Patients on immunosuppression or chemotherapy}

Reactivation of $\mathrm{HBV}$ replication with decompensation has been reported in $20-50 \%$ of patients with chronic HBV infection undergoing cancer chemotherapy or immunosuppressive therapy, especially those containing high-dose steroid regimen. Reactivation commonly occurs after the first 2-3 cycles of chemotherapy. High viral load at baseline is the most important risk factor for $\mathrm{HBV}$ reactivation [106]. HBV reactivation following transarterial chemoembolization was also observed in $34 \%$ of 83 patients with HCC [107]. Lamivudine is effective in the treatment of $\mathrm{HBV}$ reactivation in $\mathrm{HBsAg}$-positive organ transplantation recipients and cancer patients undergoing chemotherapy, particularly if it is used preemptively. Prophylactic use of lamivudine within 1 week before the start and continued at least 12 weeks after end of chemotherapy, and when white blood cell count has normalized, can reduce $\mathrm{HBV}$ reactivation frequency and severity of flares and improve survival [106].

The impact of immunosuppressive therapy on patients with occult HBV infection is poorly characterized. In a recent study involving 244 consecutive HBsAg-negative lymphoma patients who received chemotherapy, $8(3.3 \%)$ developed de novo HBV-related hepatitis and 3 with fulminant hepatic failure, following a 100-fold increase in serum HBV-DNA levels. These patients responded to lamivudine, but one died of hepatic failure. These findings suggest that even in an HBV endemic area, the occurrence of de novo HBV-related hepatitis after chemotherapy is low. It was suggested that $\mathrm{HBsAg-negative} \mathrm{patients,}$ especially those receiving rituximab plus steroid-containing regimen, should be closely monitored to facilitate early commencement of nucleoside/nucleotide analogues [108].

\section{Liver transplantation for chronic $H B V$ infection}

Liver transplantation has become a cost-effective treatment of liver failure and HCC with excellent 5-year survival. Improving economies and live related liver donation have allowed a rapid expansion of liver transplantation within the Asia-Pacific region where hepatitis $B$ is the most common indication for both acute and chronic liver failure. Acute or chronic HBV infection accounts for most cases of acute liver failure in this region, whereas more than $80 \%$ of cases of chronic liver failure and HCC are caused by chronic $\mathrm{HBV}$ infection. Although $\mathrm{HBV}$ recurrence can be prevented in $60 \%$ of cases by high-dose $(10,000 \mathrm{U} / \mathrm{month})$ intravenous hepatitis B immunoglobulin (HBIg), this therapy is prohibitively expensive (US\$50,000 per annum, lifelong) and is ineffective in transplant candidates with detectable HBV-DNA. Suppression of pretransplant viral replication significantly reduces the risk of posttransplant recurrence. In addition, viral suppression rescues some patients with decompensated cirrhosis, thereby removing the need for future transplant [103].

Antiviral therapy should be commenced in all potential liver transplant candidates with decompensated HBV cirrhosis and detectable HBV-DNA. However, posttransplant HBV recurrence may still occur despite antiviral prophylaxis and is usually due to lamivudine resistance [1]. Adefovir and entecavir are available for rescue therapy for 
lamivudine resistance, and de novo use of these agents may minimize the problems of drug resistance. Combination lamivudine/HBIg prophylaxis reduces recurrence rates of HBV infection to less than $5 \%$ and is associated with 5year patient and graft survival rates of $85 \%$ and $80 \%$, respectively. A recent long-term (median $=62$ months) follow-up study involving 147 patients has shown that lamivudine plus low-dose intramuscular HBIg (400-800 U daily for 1 week, then monthly) appears as effective as lamivudine plus high-dose intravenous HBIg, but is less than $10 \%$ the cost (US\$4,000) [109]. A recent study suggested that late HBIg substitution by adefovir (at least 12 months posttransplant) can prevent late HBV recurrence at less cost [110] In a prospective open-labeled study, lamivudine plus adefovir combination from the time of listing was well tolerated, prevented lamivudine resistance prior to transplant, rescued some patients from the need for transplantation, and prevented recurrent $\mathrm{HBV}$ infection following liver transplantation, regardless of baseline HBV-DNA status [111] Both studies demonstrate that lamivudine plus adefovir combination prophylaxis has similar efficacy to current lamivudine plus HBIg prophylaxis but without the cost and inconvenience of long-term monthly HBIg administration. There is emerging data that HBIg \pm lamivudine prophylaxis can be replaced by lamivudine monotherapy 12 months posttransplant in certain "low-risk" patient groups. These include patients who were HBV-DNA negative (hybridization assay) before pretransplant lamivudine therapy was started and patients with sustained protective levels of anti-HBs production following posttransplant vaccination.

Adoptive immune transfer may result in de novo antiHBs production in recipients of live related liver graft from an HBV immune donor. A liver from anti-HBc(+) donor carries a significant risk of de novo HBV infection if transplanted into an HBV-naïve recipient. This risk becomes negligible if the recipient receives long-term prophylaxis with either lamivudine or HBIg or if the recipient is seronegative for HBsAg but positive for antiHBs.

\section{Issues and recommendations}

Based on this background information, the following issues and recommendations for management of chronic HBV infection are listed. The recommendations were based on evidences graded as I (at least 1 well-designed, randomized control trial), II (well-designed cohort or case-controlled studies), III (case series, case reports, or flawed clinical trials), and IV (opinions of respected authorities based on clinical experience, descriptive studies, or reports of expert committees).
General management

Before active therapy, a thorough evaluation of the patient is essential. A complete blood cell count, biochemical tests, and HBV replication status should be part of the initial evaluation. Besides drug therapy directed at liver disease, counseling of the patient is also very important and even crucial for a successful antiviral therapy. This should include information on the infectivity/transmission of HBV and preventive measures for family members and sexual contacts (e.g., vaccination); advice on lifestyle such as activity, diet, alcohol use, risk behaviors, and factors that predispose to superinfection with other hepatitis virus(es) and their prevention; the importance and need for careful follow-up and long-term monitoring, and possible therapy. Health-related quality of life assessment has shown that patients with chronic HBV infection attribute a wide range of negative psychological, social, and physical symptoms to their condition even in the absence of cirrhosis or cancer [112]. These symptoms should be considered in the counseling process. The indications, risks/benefits, advantages/ disadvantages, cost, and possible problems of each therapeutic option should be explained in detail. The therapy should be tailored for individual needs. Careful assessment on an individual basis, including likelihood of response and economic factors of individual patients, is absolutely essential before starting therapy. HBV genotyping may be considered, but is not mandatory.

Recommendation 1: Thorough evaluation and counseling are mandatory before considering drug therapy (II).

\section{Indications for treatment}

Available information suggests that patients with persistently normal ALT levels usually have minimal histologic changes and respond poorly, in terms of HBeAg seroconversion, when treated with currently available drugs. Therefore, no drug treatment is recommended for this group of patients unless they have evidence of advanced fibrosis or cirrhosis [113]. However, they should be followed up every 3 months for the first year, and then monitored every 3 months if $\mathrm{HBeAg}$ positive and every 6 months if HBeAg negative. Surveillance for HCC using ultrasonography and serum $\alpha$-fetoprotein every 3-6 months is also important for high-risk HBV-infected persons (male, age $>40$, cirrhotic, positive family history of serious liver disease) [114]. Patients with active HBV replication (positive HBeAg and/or HBV-DNA) and raised ALT levels are candidates for treatment. Liver biopsy is recommended before therapy to assess the necroinflammatory grade, determine the fibrotic stage, and exclude other possible causes of raised ALT levels as a guide to the indication for 
antiviral treatment. A liver biopsy should be considered in patients older than 40 [115], especially those with high normal ALT levels [8].

Recommendation 2: Patients with viral replication but persistently normal or minimally elevated ALT levels should not be treated, except in patients with advanced fibrosis or cirrhosis. They need adequate follow-up and HCC surveillance every 3-6 months (I).
Recommendation 3: Prior to therapy, liver biopsy is recommended in patients with $H B V$ replication and raised ALT levels, or those with high normal ALT levels and older than 40 (II).

Time to start treatment (Figs. 1-3)

Treatment may be started if patients have persistently elevated ALT level $\geq 2$ times ULN (at least 1 month between observations).
Fig. 1 Algorithm for the management of hepatitis B e antigen ( $\mathrm{HBeAg}$ )-positive patients with chronic hepatitis $B$ infection. AFP:

alphafetoprotein; ALT: alanine aminotransferase; HBV: hepatitis B virus; HCC: hepatocellular carcinoma; ULN: upper limit of normal; LT: liver transplantation
Fig. 2 Algorithm for the management of hepatitis B e antigen ( $\mathrm{HBeAg}$ )-negative patients with chronic hepatitis $B$ infection. AFP:

alphafetoprotein; ALT: alanine aminotransferase; HBV: hepatitis B virus; HCC: hepatocellular carcinoma; ULN: upper limit of normal
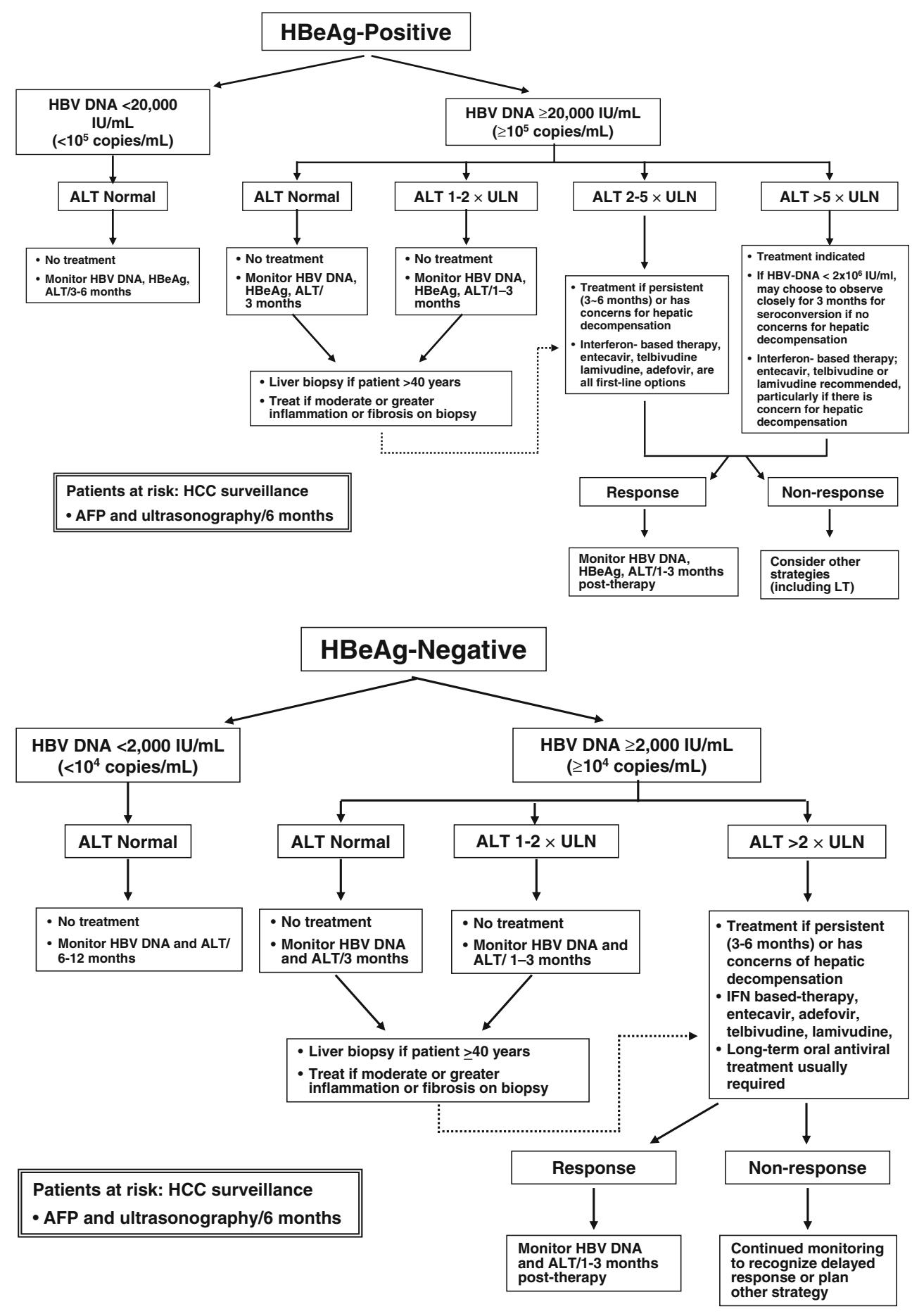
Fig. 3 Algorithm for the management of chronic hepatitis B infection with liver cirrhosis. ADV: adefovir; AFP: alphafetoprotein; ALT: alanine aminotransferase; ETV: entecavir; $\mathrm{HBeAg}$ : hepatitis B e antigen; $\mathrm{HBV}$ : hepatitis $\mathrm{B}$ virus; HCC: hepatocellular carcinoma; IFN: interferon; LAM: lamivudine; Ldt: telbivudine

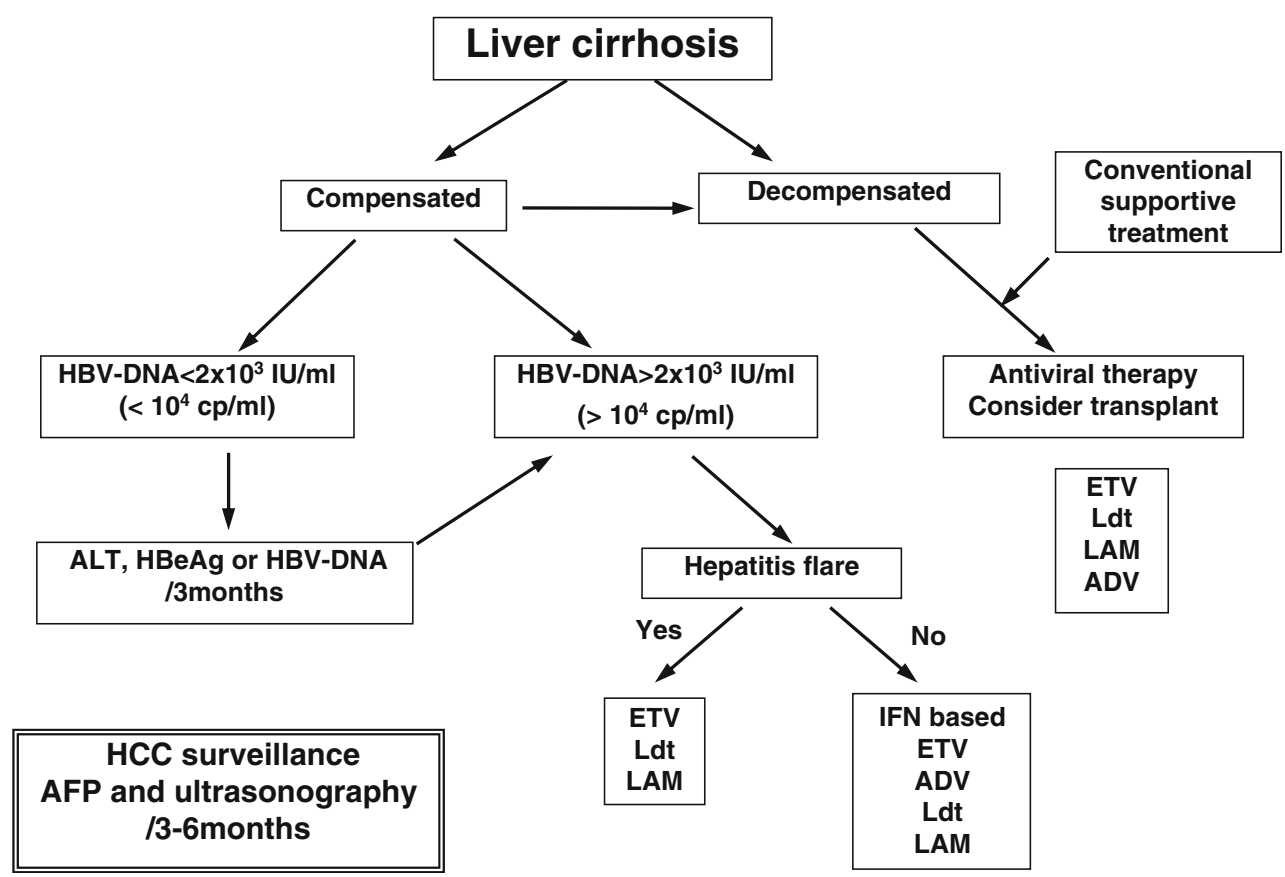

Patients with a rising trend in ALT (from normal or minimally elevated levels) or with ALT $>5$ times ULN may be developing an exacerbation and severe hepatitis or hepatic decompensation may follow, particularly those with increasing serum HBV-DNA $>10^{8}$ copies/ml [116] or in patients with advanced fibrosis [20]. They should be monitored closely for weekly or biweekly serum bilirubin levels and prothrombin time measurement. Treatment must be initiated in time to prevent the development or deterioration of hepatic decompensation. Such exacerbations, particularly in patients with declining serum HBV-DNA levels or a level less than $10^{6}$ copies $/ \mathrm{ml}$, may also precede spontaneous HBeAg seroconversion and may be followed by disease remission [9]. Due to this, it is reasonable to delay treatment for an observation period of 3 months if there is no concern about hepatic decompensation.

Recommendation 4: Chronic HBV-infected patients with $A L T>2$ times $U L N$ and $H B V-D N A>2.0 \times 10^{4} \mathrm{IU} / \mathrm{ml}$ $\left(10^{5}\right.$ copies $\left./ \mathrm{ml}\right)$ if $\mathrm{HBeAg}$ positive or $>2.0 \times 10^{3} \mathrm{IU} / \mathrm{ml}\left(10^{4}\right.$ copies $/ \mathrm{ml}$ ) if HBeAg negative should be considered for treatment (I). Treatment should be started as early as possible in case of impending or overt hepatic decompensation (II). Otherwise, 3-6 months' observation is recommended (II).

Which drugs or strategy?

Drugs currently approved for the treatment of chronic HBV infection have relatively limited sustained long-term efficacy. Therefore, the probability of sustained response, age of patient, severity of liver disease, likelihood of drug resistance, adverse events, and complications need to be carefully considered. Conventional IFN or PegIFN- $\alpha 2$ a, lamivudine, adefovir, entecavir, and telbivudine can all be considered for initial therapy in patients without liver decompensation. The rates of sustained response seem to be higher with IFN- $\alpha$ and PegIFN- $\alpha 2$ a than with direct antiviral agents, and response can be achieved with a defined duration of treatment [117]. Cirrhotic patients respond to IFN or PegIFN better than, or at least as good as, their noncirrhotic counterparts. IFN-based therapy has more side effects and requires closer monitoring.

For viremic patients (both $\mathrm{HBeAg}$ positive and $\mathrm{HBeAg}$ negative, adults and children) with ALT $>5$ times ULN, entecavir, telbivudine, or lamivudine is recommended if there is a concern about hepatic decompensation because of its rapidity of action. IFN-based therapy is also more effective in patients with higher ALT levels; it is generally not preferred in such circumstances because its therapeutic effect is not immediate and the patient may become decompensated.

For HBeAg-positive patients with an ALT level between 2 and 5 times ULN, the choice between IFN-based therapy and direct antiviral agents is less clear and either agent may be used. Theoretically, this group of patients has not mounted a high enough immune response against HBV, and thus need immunomodulation.

Corticosteroid priming before IFN or lamivudine therapy is generally not recommended and should be used cautiously and only in expert centers and not in patients with advanced disease. 
Twelve-month IFN or PegIFN- $\alpha 2$ a induces higher sustained response rates than direct antiviral agents in HBeAg-negative patients with intermittent or persistent ALT elevation, moderate to severe inflammation, fibrosis on biopsy, and serum HBV-DNA $>2,000 \mathrm{IU} / \mathrm{ml}\left(10^{4}\right.$ copies $/ \mathrm{ml}$ ). Direct antiviral agents provide other options, but long-term therapy is required and therefore the drug resistance profile of the drug to be used should be considered. The long-term ( $>5$ years) effect of IFN therapy is better known than direct antiviral agents.

The decision as to which agent to be used should be an individual one, based on disease severity, history of flares, hepatic function, the rapidity of drug action, resistance profile, side effects, costs of the drugs, and patient choice.

PegIFN- $\alpha 2 b$ has been approved for the treatment of chronic HBV infection in a few countries. This IFN has not been well studied in HBeAg-negative patients.

Recommendation 5: Patients can be treated with conventional IFN 5-10 MU 3 times per week or PegIFN- $\alpha 2$ a 90$180 \mu \mathrm{g}$ weekly (I), entecavir $0.5 \mathrm{mg}$ daily (I), adefovir $10 \mathrm{mg}$ daily (I), telbivudine $600 \mathrm{mg}$ daily (I), or lamivudine $100 \mathrm{mg}$ daily(I). Thymosin $\alpha 1.6 \mathrm{mg} 2$ times per week can also be used (I). Lamivudine is recommended if there is a concern regarding ensuing or overt hepatic decompensation (II). Entecavir and telbivudine may also be used in this situation (IV).

How to monitor?

To achieve the most cost-effective treatment, adequate monitoring during and after treatment is crucial. HBVDNA measurements should be done using assays standardized/validated to report against the WHO IU/ml reference standard. If affordable, drug-resistant testing should also be considered.

Recommendation 6: During therapy, ALT HBeAg and/or $H B V-D N A$ should be monitored at least every 3 months (I). Renal function should be monitored if adefovir is used (I). During IFN therapy, monitoring of adverse effects is mandatory (I).

Recommendation 7: After the end of therapy, levels of $A L T$ and HBV-DNA should be monitored monthly for the first 3 months to detect early relapse, and then every 3 (for cirrhotic patients and those who remain HBeAg/HBV-DNA positive) to 6 months (for responders) (II). For nonresponders, further monitoring of $H B V$ markers is required to both recognize a delayed response and plan retreatment when indicated (II).

When to stop therapy?

The recommended duration of IFN-based therapy for patients with HBeAg-positive hepatitis infection is
6-12 months irrespective of whether or not response has occurred. For HBeAg-negative patients, 12 months' therapy is required. A 6- to 12-month observation period after the end of IFN therapy is also recommended to both detect delayed response and establish whether a response is sustained, and thus whether retreatment or other therapy is required. The recommended duration of thymosin $\alpha 1$ therapy is 6 months, with 12 months' observation after end of therapy.

Since the incidence of drug resistance increases with increasing duration of direct antiviral therapy, therapy can be stopped if the patient has undergone $\mathrm{HBeAg}$ seroconversion with HBV-DNA loss measured at two consecutive occasions at least 6 months apart. For those who remain HBeAg positive, the decision to continue or stop therapy should be evaluated individually on the basis of clinical/ virologic response and disease severity. If resistant mutations emerge, early rescue therapy with other agents is indicated. For HBeAg-negative patients, the optimal duration of treatment is unknown and the decision to stop therapy should be determined by clinical response and severity of the underlying liver disease.

Recommendation 8: For conventional IFN, the current recommended duration of therapy is 4-6 months for HBeAg-positive patients (II) and at least a year for HBeAgnegative patients (I). For PegIFN, the recommended duration is at least 6 month for HBeAg-positive patients (II) and 12 months for HBeAg-negative patients (I). For thymosin $\alpha 1$, the recommended duration of therapy is 6 months for both HBeAg-positive (I) and HBeAg-negative patients (II).

Recommendation 9: For oral antiviral agents: In HBeAg-positive patients, treatment can be stopped when $H B e A g$ seroconversion with undetectable $H B V-D N A$ has been documented on 2 separate occasions at least 6 months apart (II). In HBeAg-negative patients, it is not clear how long this treatment should be continued, but treatment discontinuation can be considered if undetectable HBV-DNA has been documented on three separate occasions 6 months apart. (II).

What to do for patients in special circumstances?

Female patients in the childbearing age

When treatment is indicated in women in the childbearing age, both the drug property and the duration of dosing should be considered.

Recommendation 10: For female patients of childbearing age, IFN-based therapy is preferred for nonpregnant women and pregnancy is discouraged during IFN therapy. 
Women who become pregnant while on oral antiviral $\operatorname{drug}(s)$ can continue treatment with category $B$ drug(s) (VI).

Patients with concurrent HIV infection

All HIV-infected patients with active HBV replication and elevated serum ALT levels may be considered for treatment. Treatment needs to be individualized according to the patient's HIV status. If the infection does not fulfill treatment criteria, IFN-based therapy or adefovir monotherapy is preferred. Lamivudine or tenofovir monotherapy is not recommended in this setting because of the risk of HIV resistance. HAART containing lamivudine/tenofovir or its equivalent combination is recommended if treatment is being continued for infection.

Recommendation 11: Adefovir, telbivudine, or IFN (if $\left.\mathrm{CD}_{4}>500\right)$ is preferred if patient's HIV infection does not require treatment. If infection requires treatment, tenofovir or lamivudine/tenofovir combination should be included in the active antiretroviral therapy (II).

\section{Patients with concurrent HCV or HDV infection}

It is important to determine which virus is dominant before designing the treatment strategy.

Recommendation 12: In patients with concurrent $\mathrm{HCV}$ or HDV infection, determine which virus is dominant and treat the patients accordingly (III).

\section{Patients with decompensated liver disease}

IFN is usually contraindicated in patients with decompensated liver disease. Direct antiviral agent with potent and prompt HBV suppressive action should be used immediately.

Recommendation 13: Lamivudine is the agent of choice for treatment-naïve patients with obvious or impending hepatic decompensation (II). Entecavir and telbivudine can also be used (IV).

Patients undergoing immunosuppression or chemotherapy

$\mathrm{HBV}$ reactivation is a serious complication in patients undergoing immunosuppression or chemotherapy. Lamivudine therapy is effective when instituted early, before the occurrence of clinical jaundice and decompensation. Results are significantly better if lamivudine is used before starting chemotherapy [118]. Prophylactic treatment using other antiviral agent has not been reported.
Recommendation 14: Before receiving immunosuppression or chemotherapy, patients should be screened for HBsAg (III). If HBsAg positive, prophylactic therapy with lamivudine before the start and up to at least 12 weeks after the end of immunosuppression or chemotherapy is recommended (I). Other direct antiviral agents can also be used (IV).

\section{Patients with drug resistance}

Once drug resistance is evident by a more than $1 \mathrm{log} \mathrm{IU} / \mathrm{ml}$ increase of HBV-DNA from nadir, rescue therapy should be instituted as early as possible.

Recommendation 15: For patients who develop drug resistance while on lamivudine, add-on adefovir therapy is indicated (I); switching to entecavir (1 mg/day) is an option (I). For lamivudine-naïve patients who develop drug resistance while on adefovir, add-on or switching to lamivudine, telbivudine, or entecavir is indicated (III). For patients who develop drug resistance while on telbivudine, add-on adefovir therapy is indicated (IV). Switching to IFN-based therapy is an option (III).

\section{Patients in the setting of liver transplantation}

Nucleos(t)ide analogues are effective in pretransplant treatment, prevention (in combination with HBIg) of posttransplant $\mathrm{HBV}$ recurrence, and treatment of posttransplant HBV-related allograft infection. Adequate use of these agents has improved the outcome.

Recommendation 16-1: Nucleos(t)ide analogue(s) should be commenced in all patients with HBV-associated liver failure who are listed for transplantation and have detectable HBV-DNA. Lamivudine plus low-dose HBIg (400-800 U i.m. daily for 1 week, followed by 400-800 U monthly for long term) provides safe and effective prophylaxis against $H B V$ reinfection of the allograft (II). Alternatively, lamivudine + adefovir prophylaxis can be considered (II).

Recommendation 16-2: Late (at least 12 months posttransplant) HBIg substitution by adefovir provides safe and cost-effective prophylaxis (II). Late conversion to lamivudine monotherapy may be considered in "low-risk" patients (I).

Recommendation 16-3: HBV-naïve patient receiving a liver from anti-HBc(+) donor should receive long-term prophylaxis with either lamivudine or HBIg (III). 
Unresolved issues and areas for further study

Despite recent advances in the treatment of chronic HBV infection, the results are still unsatisfactory. In particular, the following issues remain unsettled:

1. Should HBV genotyping be routine in designing treatment plan?

2. What should be done if on-treatment response to direct antiviral agents (at 24 week?) is not satisfactory?

3. What should be the treatment strategy for children with chronic HBV infection? "Necessity" or "likelihood to respond"?

4. Is there more effective therapy for patients with chronic HDV infection?

5. What is the role of corticosteroid withdrawal, lamivudine pulse therapy, or other immunomodulating agents and modes of immunomodulation?

6. What is the optimal combination therapy to enhance efficacy?

7. Cost-effectiveness of each therapeutic strategy.

The development of new drugs and new strategies, especially combination or sequential antiviral therapy, is the highest priority in further improving the outcomes of treatment.

Acknowledgment The expert pre-meeting was sponsored by the Liver Society of Thailand.

Open Access This article is distributed under the terms of the Creative Commons Attribution Noncommercial License which permits any noncommercial use, distribution, and reproduction in any medium, provided the original author(s) and source are credited.

\section{References}

1. Liaw YF, Leung N, Guan R, Lau GKK, Merican I, McCaughan G et al. Asian-Pacific consensus statement on the management of chronic hepatitis B: a 2005 update. Liver Int 2005;25:472-489.

2. Keeffe EB, Dieterich DT, Han SH, Jacobson IM, Martin P, Schiff ER et al. A treatment algorithm for the management of chronic hepatitis B virus infection in the United States: an update. Clin Gastroenterol Hepatol 2006;4:936-962.

3. ACT-HBV Asia-Pacific Steering Committee Members. Chronic hepatitis B: treatment alert. Liver Int 2006;26:47-58.

4. Lok AS, McMahon BJ. Chronic hepatitis B. Hepatology 2007;45:507-539.

5. Summers J, Mason WS. Replication of the genome of a hepatitis B-like virus by reverse transcription of an RNA intermediate. Cell 1982;29:403-415.

6. Yokosuka O, Omata M, Imazeki F, Okuda K, Summers J. Changes of hepatitis B virus DNA in liver and serum caused by recombinant leukocyte interferon treatment: analysis of intrahepatic replicative hepatitis $B$ virus DNA. Hepatology 1985;5:728-734.

7. Hui CK, Leung N, Yuen ST, Zhang HY, Leung KW, Lu L et al. Natural history and disease progression in Chinese chronic hepatitis B patients in immune-tolerant phase. Hepatology 2007;46:395-401.

8. Lai M, Hyatt BJ, Nasser I, Curry M, Afdhal NH. The clinical significance of persistently normal ALT in chronic hepatitis B infection. J Hepatol 2007;47:760-767.

9. Liaw YF. Hepatitis flares and hepatitis B e antigen seroconversion: implication in anti-hepatitis B virus therapy. J Gastroenterol Hepatol 2003;18:246-252.

10. Chu CM, Liaw YF. Genotype C hepatitis B virus infection is associated with a higher risk of reactivation of hepatitis $B$, progression to cirrhosis than genotype B: a longitudinal study of hepatitis B e antigen-positive patients with normal aminotransferase levels at baseline. J Hepatol 2005;43:411-417.

11. Chu CM, Hung SJ, Lin J, Tai DI, Liaw YF. Natural history of hepatitis $\mathrm{B}$ e antigen to antibody seroconversion in patients with normal serum aminotransferase levels. Am J Med 2004;116:829-834.

12. Hsu YS, Chien RN, Yeh CT, Sheen IS, Chiou HY, Chu CM. Long-term outcome after spontaneous $\mathrm{HBe} A g$ seroconversion in patients with chronic hepatitis B. Hepatology 2002;35:15221527.

13. Chu CM, Liaw YF. Predictive factors for reactivation of hepatitis $\mathrm{B}$ following hepatitis $\mathrm{B}$ e antigen seroconversion in chronic hepatitis B. Gastroenterology 2007;133:1458-1465.

14. Chu CM, Liaw YF. Spontaneous relapse of hepatitis in inactive HBsAg carriers. Hepatol Int 2007;1:311-315.

15. Feld JJ, Ayers M, El-Ashry D, Mazzulli T, Tellier R, Heathcote EJ. Hepatitis B virus DNA prediction rules for hepatitis B e antigen-negative chronic hepatitis B. Hepatology 2007;46:10571070.

16. Liaw YF, Tai DI, Chu CM, Chen TJ. The development of cirrhosis in patients with chronic type $\mathrm{B}$ hepatitis: a prospective study. Hepatology 1988;8:493-496.

17. Lin SM, Yu ML, Lee CM, Chien RN, Sheen IS, Chu CM et al. Interferon therapy in $\mathrm{HBeAg}$ positive chronic hepatitis reduces cirrhosis and hepatocellular carcinoma. J Hepatol 2007:46:45-52.

18. Park BK, Park YN, Ahn SH, Lee KS, Chon CY, Moon YM et al. Long-term outcome of chronic hepatitis B based on histological grade and stage. J Gastroenterol Hepatol 2007;22:383-388.

19. Chen YC, Chu CM, Yeh CT, Liaw YF. Natural course following the onset of cirrhosis in patients with chronic hepatitis B: a longterm follow-up study. Hepatol Int 2007;1:267-273.

20. Chu CM, Liaw YF. Hepatitis B virus-related cirrhosis: natural history and treatment. Semin Liver Dis 2006;26:142-152.

21. Yang HI, Lu SN, Liaw YF, You SL, Sun CA, Wang LY et al. Hepatitis B e antigen and the risk of hepatocellular carcinoma. N Engl J Med 2002;347:168-174.

22. Yu MW, Yeh SH, Chen PJ, Liaw YF, Lin CL, Liu CJ et al. Hepatitis B virus genotype and DNA level and hepatocellular carcinoma: a prospective study in men. J Natl Cancer Inst 2005;97:265-272.

23. Iloeje UH, Yang HI, Su J, Jen CL, You SL, Chen CJ et al. Predicting cirrhosis risk based on the level of circulating hepatitis B viral load. Gastroenterology 2006;130:678-686.

24. Chen CJ, Yang HI, Su J, Jen CL, You SL, Lu SN et al. Risk of hepatocellular carcinoma across a biological gradient of serum hepatitis B virus DNA level. JAMA 2006;295:65-73.

25. Chou YC, Yu MW, Wu CF, Yang SY, Lin CL, Liu CJ et al. Temporal relationship between hepatitis B virus enhancer II/ basal core promoter sequence variation and risk of hepatocellular carcinoma. Gut 2008;57:91-97.

26. Chu CM, Liaw YF. HBsAg seroclearance in asymptomatic carriers of high endemic areas: appreciably high rates during a long-term follow up. Hepatology 2007;45:1187-1192.

27. Chen YC, Sheen IS, Chu CM, Liaw YF. Prognosis following spontaneous HBsAg seroclearance in chronic hepatitis B 
patients with or without concurrent infection. Gastroenterology 2002;123:1084-1089.

28. Yuen MF, Wong DK, Sablon E, Tse E, Ng IO, Yuan HJ et al. HBsAg seroclearance in chronic hepatitis B in the Chinese: virological, histological, and clinical aspects. Hepatology 2004;39:1694-1701.

29. Kao JH. Role of viral factors in the natural course and therapy of chronic hepatitis B. Hepatol Int 2007;1:415-430.

30. Livingston SE, Simonetti JP, Bulkow LR, Homan CE, Snowball $\mathrm{MM}$, Cagle $\mathrm{HH}$ et al. Clearance of hepatitis B e antigen in patients with chronic hepatitis B and genotypes A, B, C, D, and F. Gastroenterology 2007;133:1452-1457.

31. Ni YH, Chang MH, Wang KJ, Hsu HY, Chen HL, Kao JH et al. Clinical relevance of hepatitis B virus genotype in children with chronic infection and hepatocellular carcinoma. Gastroenterology 2004;127:1733-1738.

32. Mahmood S, Niiyama G, Kamei A, Izumi A, Nakata K, Ikeda H et al. Influence of viral load and genotype in the progression of hepatitis B-associated liver cirrhosis to hepatocellular carcinoma. Liver Int 2005;25:220-225.

33. Kao JH, Chen PJ, Lai MY, Chen DS. Hepatitis B virus genotypes and spontaneous hepatitis $\mathrm{B}$ e antigen seroconversion in Taiwanese hepatitis B carriers. J Med Virol 2004; 72:363-369.

34. Chan HL, Hui AY, Wong ML, Tse AM, Hung LC, Wong VW et al. Genotype C hepatitis B virus infection is associated with an increased risk of hepatocellular carcinoma. Gut 2004;53:1494-1498.

35. Yuen MF, Wong DK, Zheng BJ, Chan CC, Yuen JC, Wong BC et al. Difference in $\mathrm{T}$ helper responses during hepatitis flares in hepatitis $\mathrm{B}$ e antigen ( $\mathrm{HBeAg}$ )-positive patients with genotypes $\mathrm{B}$ and $\mathrm{C}$ : implication for early $\mathrm{HBeAg}$ seroconversion. J Viral Hepat 2007;14:269-275.

36. Thakur V, Guptan RC, Kazim SN, Malhotra V, Sarin SK. Profile, spectrum and significance of HBV genotypes in chronic liver disease patients in the Indian subcontinent. J Gastroenterol Hepatol 2002;17:165-170.

37. Kao JH, Chen PJ, Lai MY, Chen DS. Basal core promoter mutations of hepatitis B virus increase the risk of hepatocellular carcinoma in hepatitis B carriers. Gastroenterology 2003; 124:327-334.

38. Chen CH, Hung CH, Lee CM, Hu TH, Wang JH, Wang JC et al. Pre-S deletion and complex mutations of hepatitis $\mathrm{B}$ virus related to advanced liver disease in $\mathrm{HBeAg}$-negative patients. Gastroenterology 2007;133:1466-1474.

39. Chien RN. Current therapy for hepatitis C or D or immunodeficiency virus concurrent infection with chronic hepatitis $\mathrm{B}$. Hepatol Int 2008. doi:10.1007/s12072-008-9066-1.

40. Liaw YF. Hepatitis B virus replication and liver disease progression: the impact of antiviral therapy. Antivir Ther 2006; 11:669-679.

41. Piratvisuth T. Immunomodulator therapy of chronic hepatitis B. Hepatol Int 2008. doi:10.1007/s12072-008-9046-5.

42. Iorio R, Giannattasio A, Cirillo F, D'Alessandro L, Vegnente A. Long-term outcome in children with chronic hepatitis B: a 24year observation period. Clin Infect Dis 2007;45:943-949.

43. Mellerup MT, Krogsgaard K, Mathurin P, Gluud C, Poynard T. Sequential combination of glucocorticosteroids and alfa interferon versus alfa interferon alone for $\mathrm{HBeAg}$-positive chronic hepatitis B. Cochrane Database Syst Rev 2005;(3):CD000345. Review.

44. Niederau C, Heintges T, Lange S, Goldmann G, Niederau CM, Mohr L et al. Long-term follow-up of $\mathrm{HBeAg}$-positive patients treated with interferon alfa for chronic hepatitis B. N Engl J Med 1996;334:1422-1427.
45. Papatheodoridis GV, Manesis E, Hadziyannis SJ. The long-term outcome of interferon-alpha treated and untreated patients with HBeAg-negative chronic hepatitis B. J Hepatol 2001;34:306313.

46. Cooksley WG, Piratvisuth T, Lee SD, Mahachai V, Chao YC, Tanwandee $\mathrm{T}$, et al. Peginterferon alpha-2a (40 kDa): an advance in the treatment of hepatitis $\mathrm{B}$ e antigen-positive chronic hepatitis B. J Viral Hepat 2003;10:298-305.

47. Lau GK, Piratvisuth T, Luo KX, Marcellin P, Thongsawat S, Cooksley $\mathrm{G}$ et al. Peginterferon alfa-2a, lamivudine, and the combination for HBeAg-positive chronic hepatitis B. N Engl J Med 2005;352:2682-2695.

48. Marcellin P, Lau GKK Bonino $\mathrm{F}$ et al. Peginterferon alfa-2a alone, lamivudine alone and the two in combination in patients with $\mathrm{HBeAg}$ negative chronic hepatitis B. N Engl J Med 2004;351:1206-1217.

49. Piratvisuth T, Lau G, Chao YC, Jin R, Chutaputti A, Zhang QB et al. Sustained response to peginterferon alfa-2a (40 kDa) with or without lamivudine in Asian patients with $\mathrm{HBeAg}$-positive and $\mathrm{HBeAg-negative} \mathrm{chronic} \mathrm{hepatitis} \mathrm{B.} \mathrm{Hepatol} \mathrm{Int}$ 2008;2:102-110.

50. Buster EH, Hansen BE, Buti M, Delwaide J, Niederau C, Michielsen PP et al. Peginterferon alpha- $2 b$ is safe and effective in $\mathrm{HBeAg-positive} \mathrm{chronic} \mathrm{hepatitis} \mathrm{B} \mathrm{patients} \mathrm{with} \mathrm{advanced}$ fibrosis. Hepatology 2007;46:388-394.

51. Flink HJ, Hansen BE, Heathcote EJ, Feinman SV, Simsek H, Karayalcin $S$ et al. Successful treatment with peginterferon alfa$2 \mathrm{~b}$ of $\mathrm{HBeAg}$-positive HBV non-responders to standard interferon or lamivudine. Am J Gastroenterol 2006;101:2523-2529.

52. Flink HJ, Sprengers D, Hansen BE, van Zonneveld M, de Man RA, Schalm SW et al. Flares in chronic hepatitis B patients induced by the host or the virus? Relation to treatment response during Peg-interferon \{alpha\}-2b therapy. Gut 2005;54:16041609.

53. Fried MW, Piratvisuth T, Lau GK, Marcellin P, Chow WC, Cooksley $\mathrm{G}$ et al. HBeAg and hepatitis B virus DNA as outcome predictors during therapy with peginterferon alfa-2a for $\mathrm{HBeAg}$ positive chronic hepatitis B. Hepatology 2008;47:428-434.

54. Bonino F, Marcellin P, Lau GK, Hadziyannis S, Jin R, Piratvisuth $\mathrm{T}$ et al. Predicting response to peginterferon alpha-2a, lamivudine and the two combined for $\mathrm{HBeAg-negative} \mathrm{chronic}$ hepatitis B. Gut 2007;56:699-705.

55. Janssen HLA, van Zonneveld M, Senturk H, Zeuzem S, Akarca US, Cakaloglu $\mathrm{Y}$ et al. Pegylated interferon alfa- $2 \mathrm{~b}$ alone or in combination with lamivudine for $\mathrm{HBeAg}$-positive chronic hepatitis B: a randomised trial. Lancet 2005;365:123-129.

56. Sarin SK, Sood A, Kumar M, Arora A, Amrapurkar D, Sharma BC et al. Effect of lowering HBV DNA levels by initial antiviral therapy before adding immunomodulator on treatment of chronic hepatitis B. Am J Gastroenterol 2007;102:96-104.

57. Lim SG, Wai CT, Lee YM, Dan YY, Sutedja DS, Wee A et al. A randomized, placebo-controlled trial of thymosin-alpha1 and lymphoblastoid interferon for $\mathrm{HBeAg}$-positive chronic hepatitis B. Antivir Ther 2006;11:245-253.

58. Chien RN, Liaw YF, Chen TC, Yeh CT, Sheen IS. Efficacy of thymosin $\alpha 1$ in patients with chronic type B hepatitis: a randomized controlled trial. Hepatology 1998;27:1383-1387.

59. You J, Zhuang L, Cheng HY, Yan SM, Qiao YW, Huang JH et al. A randomized, controlled, clinical study of thymosin alpha-1 versus interferon-alpha in [corrected] patients with chronic hepatitis B lacking HBeAg in China [corrected] J Chin Med Assoc 2005;68:65-72.

60. Chien RN, Lin CY, Yeh CT, Liaw YF. Hepatitis B virus genotypes B is associated with better response to thymosin $\alpha 1$ therapy than genotype C. J Viral Hepat 2006;13:845-850. 
61. Iino S, Toyota J, Kumada H, Kiyosawa K, Kakumu S, Sata M et al. The efficacy and safety of thymosin alpha-1 in Japanese patients with chronic hepatitis B; results from a randomized clinical trial. J Viral Hepat 2005;12:300-306.

62. Chan HL, Tang JL, Tam W, Sung JJ. The efficacy of thymosin in the treatment of chronic hepatitis B virus infection: a metaanalysis. Aliment Pharmacol Ther 2001;15:1899-1905.

63. Vandepapeli'ere P, Lau GKK, Leroux-Roels G, Horsmans Y, Gane E, Tawandee $\mathrm{T}$ et al. Therapeutic vaccination of chronic hepatitis B patients with virus suppression by antiviral therapy: a randomized, controlled study of co-administration of HBsAg/ AS02 candidate vaccine and lamivudine. Vaccine 2007;25: $8585-8597$.

64. Leung N. Recent data on treatment of chronic hepatitis B with nucleos(t)ide analogues. Hepatol Int 2008. doi:10.1007/ s12072-008-9061-6.

65. Liaw YF. Results of lamivudine trials in Asia. J Hepatol 2003;39:S111-S115.

66. Jonas MM, Little NR, Gardner SD, Members of the International Pediatric Lamivudine Investigator Group*. Long-term lamivudine treatment of children with chronic hepatitis B: durability of therapeutic responses and safety. J Viral Hepat 2008;15:20-27.

67. Chien RN, Yeh CT, Tsai SL, Chu CM, Liaw YF. The determinants for sustained $\mathrm{HBeAg}$ response to lamivudine therapy. Hepatology 2003;38:1267-1273.

68. Chein RN, Liaw YF. Short-term lamivudine therapy in HBeAgnegative chronic active hepatitis B in Taiwan. Antivir Ther 2006;11:947-952.

69. Fung SK, Wong F, Hussain M, Lok AS. Sustained response after a 2-year course of lamivudine treatment of hepatitis B e antigen-negative chronic hepatitis B. J Viral Hepat 2004;11: $432-438$.

70. Chan HL, Wang H, Niu J, Chim AM, Sung JJ. Two-year lamivudine treatment for hepatitis $\mathrm{B}$ e antigen-negative chronic hepatitis B: a double-blind, placebo-controlled trial. Antivir Ther 2007;12:345-353.

71. Liaw YF, Sung JJY, Chow WC, Farrell G, Lee CZ, Yuen H et al. Lamivudine for patients with chronic hepatitis B and advanced liver disease. N Engl J Med 2004;351:1521-1531.

72. Lok AS, Zoulim F, Locarnini S, Bartholomeusz A, Ghany MG, Pawlotsky JM et al. Antiviral drug-resistant HBV: standardization of nomenclature and assays and recommendations for management. Hepatology 2007;46:254-265.

73. Locarnini S. Primary resistance, multidrug resistance and crossresistance pathways in $\mathrm{HBV}$ as a consequence of treatment failure. Hepatol Int 2008. doi:10.1007/s12072-008-9048-3.

74. Liaw YF, Chien RN, Yeh CT, Tsai SL, Chu CM. Acute exacerbation and hepatitis $\mathrm{B}$ virus clearance after emergence of YMDD motif mutation during lamivudine therapy. Hepatology 1999;30:567-572.

75. Yeh CT, Chien RN, Chu CM, Liaw YF. Clearance of the original hepatitis B virus YMDD-motif mutants with emergence of distinct lamivudine-resistant mutants during prolonged lamivudine therapy. Hepatology 2000;31:1318-1326.

76. Leung NW, Lai CL, Chang TT, Guan R, Lee CM, Ng KY et al. Extended lamivudine treatment in patients with chronic hepatitis $\mathrm{B}$ enhances hepatitis B e antigen seroconversion rates: results after 3 years of therapy. Hepatology 2001;33:1527-1532.

77. Di Marco V, Marzano A, Lampertico P, Andreone P, Santantonio T, Almasio PL et al. Clinical outcome of HBeAg-negative chronic hepatitis B in relation to virological response to lamivudine. Hepatology 2004;40:883-891.

78. Liaw YF, Tsai SL, Chien RN, Yeh CT, Chu CM. Prednisolone priming enhances Th1 response and efficacy of subsequent lamivudine therapy in patients with chronic hepatitis B. Hepatology 2000;32:604-609.

79. Sarin SK, Sandhu BS, Sharma BC, Jain M, Singh J, Malhotra V. Beneficial effects of "lamivudine pulse" therapy in $\mathrm{HBeAg}$ positive patients with normal ALT. J Viral Hepat 2004;11:552558.

80. Hadziyannis SJ, Tassopoulos NC, Heathcote EJ, Chang TT, Kitis G, Rizzetto $M$ et al. Long-term therapy with adefovir dipivoxil for HBeAg-negative chronic hepatitis B for up to 5 years. Gastroenterology 2006;131:1743-1751.

81. Liaw YF, Lee CM, Chien RN, Yeh CT. Switching to adefovir monotherapy after emergence of lamivudine resistant mutations in patients with liver cirrhosis. J Viral Hepat 2006;13: 250-255.

82. Rapti I, Dimou E, Mitsoula P, Hadziyannis SJ. Adding-on versus switching-to adefovir therapy in lamivudine-resistant $\mathrm{HBeAg}$ negative chronic hepatitis B. Hepatology 2007;45:307-313.

83. Lampertico P, Viganò M, Manenti E, Iavarone M, Sablon E, Colombo M. Low resistance to adefovir combined with lamivudine: a 3-year study of 145 lamivudine-resistant hepatitis B patients. Gastroenterology 2007;133:1445-1451.

84. Lampertico P, Vigano M, Manenti E, Iavarone M, Lunghi G, Colombo M. Adefovir rapidly suppresses hepatitis B in HBeAgnegative patients developing genotypic resistance to lamivudine. Hepatology 2005;42:1414-1419.

85. Liaw YF. Rescue therapy for lamivudine-resistant chronic hepatitis B: when and how? Hepatology 2007;26:266-268.

86. Chang TT, Gish RG, de Man R, Gadano A, Sollano J, Chao YC et al. A comparison of entecavir and lamivudine for $\mathrm{HBeAg}$ positive chronic hepatitis B. N Engl J Med 2006;354:1001-1010.

87. Lai CL, Shouval D, Lok AS, Chang TT, Cheinquer H, Goodman $\mathrm{Z}$ et al. Entecavir versus lamivudine for patients with $\mathrm{HBeAg}$ negative chronic hepatitis B. N Engl J Med 2006;354:10111020.

88. Gish RG, Lok AS, Chang TT, de Man RA, Gadano A, Sollano J et al. Entecavir therapy for up to 96 weeks in patients with HBeAg-positive chronic hepatitis B. Gastroenterology 2007;133:1437-1444.

89. Sherman M, Yurdaydin C, Sollano J, Silva M, Liaw YF, Cianciara $\mathrm{J}$ et al. Entecavir for treatment of lamivudine-refractory, HBeAg-positive chronic hepatitis B. Gastroenterology 2006;130:2039-2049.

90. Lai CL, Gane E, Liaw YF, Hsu CW, Thongsawat S, Wang Y, et al. Telbivudine versus lamivudine in patients with chronic hepatitis B. N Engl J Med 2007;357:2576-2588.

91. Chan HL, Heathcote EJ, Marcellin P, Lai CL, Cho M, Moon YM et al. Treatment of hepatitis B e antigen positive chronic hepatitis with telbivudine or adefovir: a randomized trial. Ann Intern Med 2007;147:745-754.

92. Yoo BC, Kim JH, Chung YH, Lee KS, Paik SW, Ryu SH et al. Twenty-four-week clevudine therapy showed potent and sustained antiviral activity in $\mathrm{HBeAg}$-positive chronic hepatitis B. Hepatology 2007;45:1172-1178.

93. Yoo BC, Kim JH, Kim TH, Koh KC, Um SH, Kim YS et al. Clevudine is highly efficacious in hepatitis B e antigen-negative chronic hepatitis B with durable off-therapy viral suppression. Hepatology 2007;46:1041-1048.

94. van Bommel F, Wunsche T, Mauss S, Reinke P, Bergk A, Schurmann D et al. Comparison of adefovir and tenofovir in the treatment of lamivudine-resistant hepatitis B virus infection. Hepatology 2004;40:1421-1425.

95. Hann HW, Chae HB, Dunn SR. Tenofovir (TDF) has stronger antiviral effect than adefovir (ADV) against lamivudine (LAM) resistant hepatitis B virus (HBV). Hepatol Int 2008. doi: 10.1007/s12072-008-9045-6. 
96. Marcellin P, Heathcote J, Gane E, Balabanska R, Husa P, Gurel $\mathrm{S}$, et al. Tenofovir disoproxil fumarate (TDF) demonstrated superior antiviral efficacy to adefovir dipivoxil in two pivotal, randomized, double-blind, studies for the treatment of $\mathrm{HBeAg}-$ negative and $\mathrm{HBeAg}$-positive chronic hepatitis B (CHB): study 102 and study 103. Hepatol Int 2008;2:A139.

97. Gane E. The roadmap concept: using early on-treatment virologic responses to optimize long-term outcomes for patients with chronic hepatitis B. Hepatol Int 2008; In press.

98. Dan YY, Aung MO, Lim SG. The economics of treating chronic hepatitis B in Asia. Hepatol Int 2008; In press.

99. Hoofnagle JH, Doo E, Liang TJ, Fleischer R, Lok AS. Management of hepatitis B: summary of a clinical research workshop. Hepatology 2007;45:1056-1075.

100. Farci P, Chessa C, Balestrieri C, Serra G, Lai ME. Treatment of chronic hepatitis D. J Viral Hepat 2007;14(Suppl 1):58-63.

101. Canbakan B, Senturk H, Tabak F, Akdogan M, Tahan V, Mert A et al. Efficacy of interferon alpha- $2 b$ and lamivudine combination treatment in comparison to interferon alpha- $2 b$ alone in chronic delta hepatitis: a randomized trial. J Gastroenterol Hepatol 2006;21:657-663.

102. Chien RN, Lin CH, Liaw YF. The effect of lamivudine therapy in hepatic decompensation during acute exacerbation of chronic hepatitis B. J Hepatol 2003;38:322-327.

103. Fontana RJ, Hann HW, Perrillo RP, Vierling JM, Wright T, Rakela $\mathrm{J}$ et al. Determinants of early mortality in patients with decompensated chronic hepatitis B treated with antiviral therapy. Gastroenterology 2002;123:719-727.

104. Schiff ER, Lai CL, Hadziyannis S et al. Adefovir dipivoxil therapy for lamivudine-resistant hepatitis B in pre- and postliver transplantation. Hepatology 2003;38:1419-1427.

105. Sokal E, Kelly D, Wirth S, Mizerski J, Lu B, Kleber K et al. The pharmacokinetics (PK) and safety of a single dose of adefovir dipivoxil (ADV) in children and adolescents aged 2-17 with chronic hepatitis B. J Heptol 2004;40(Suppl 1):132.

106. Lau GKK. Hepatitis B reactivation after chemotherapy-two decades of clinical research. Hepatol Int 2008. doi: 10.1007/s12072-008-9056-3.

107. Jang JW, Choi JY, Bae SH, Kim CW, Yoon SK, Cho SH et al. Transarterial chemo-lipiodolization can reactivate hepatitis B virus replication in patients with hepatocellular carcinoma. J Hepatol 2004;41:427-435.
108. Hui CK, Cheung WWW, Au WY, Zhang HY, Yueng YH, Leung $\mathrm{N}$ et al. Rituximab increases the risk of de novo hepatitis B infection in hepatitis B surface antigen negative patients undergoing cytotoxic chemotherapy. Gastroenterology 2006;131:59-68.

109. Gane EJ, Angus PW, Strasser S, Crawford DH, Ring J, Jeffrey GP et al. Lamivudine plus low-dose hepatitis B immunoglobulin to prevent recurrent hepatitis B following liver transplantation. Gastroenterology 2007;132:931-937.

110. Angus P, Strasser S, Patterson S, McCaughan G, Gane E. A randomized study to assess the safety and efficacy of adefovir dipivoxil substitution for hepatitis B immune globulin in liver transplantation patients receiving long-term low dose IM HBIg and lamivudine prophylaxis. Hepatology 2007;46:238A.

111. Gane E, Strasser S, Patterson S, McCaughan G, Angus P. A prospective study on the safety and efficacy of lamivudine and adefovir prophylaxis in $\mathrm{HBsAg}$ positive liver transplantation candidates. Hepatology 2007;46:479A.

112. Ong SC, Mak B, Aung MO, Li SC, Lim SG. Health-related quality of life in chronic hepatitis B patients. Hepatology 2008;47:1108-1117.

113. Han KH. Chronic HBV infection with persistently normal ALT: not to treat. Hepatol Int 2008. doi:10.1007/s12072-008-9068-z.

114. Liaw YF. Prevention and surveillance of hepatitis B virusrelated hepatocellular carcinoma. Semin Liver Dis 2005;25(Suppl 1):40-47.

115. Chu CM, Liaw YF. Chronic hepatitis B virus infection acquired in childhood: special emphasis on prognostic and therapeutic implication of delayed $\mathrm{HBeAg}$ seroconversion. J Viral Hepat 2007; 14:147-152.

116. Sheen IS, Hsu CW, Chen YC, Yeh CT, Chu CM, Liaw YF. Timing of lamivudine in treating acute exacerbation of chronic hepatitis B: role of HBV viral load. Hepatol Int 2007;1:125.

117. Lau G, Marcellin P, Peters M. Chronic hepatitis B: a global health problem requiring coherent worldwide treatment strategies. Hepatol Int 2007;1:316-325.

118. Hsu C, Hsiung C, Su IJ, Hwang WS, Wang MC, Lin SF et al. A revisit for prophylactic lamivudine for chemotherapy-associated hepatitis B reactivation in non-Hodgkin's lymphoma: a randomized trial. Hepatology 2008;47:844-853. 